\title{
pharmaceuticals
}

ISSN 1424-8247

www.mdpi.com/journal/pharmaceuticals

Review

\section{Epigenetic Control and Cancer: The Potential of Histone Demethylases as Therapeutic Targets}

\section{Fernando Lizcano * and Jeison Garcia}

Center of Biomedical Research La Sabana University-CIBUS, School of Medicine, Universidad de La Sabana, Campus Del Puente del Común, km 7 Autopista Norte de Bogota, Chía 250001, Colombia; E-Mail: jeisongase@unisabana.edu.co (J.G.)

* Author to whom correspondence should be addressed; E-Mail: fernandoll@unisabana.edu.co; Tel.: +571-861-5555 (ext. 23328); Fax: +571-861-5555 (ext. 10111).

Received: 26 June 2012; in revised form: 21 July 2012 / Accepted: 17 August 2012 /

Published: 12 September 2012

\begin{abstract}
The development of cancer involves an immense number of factors at the molecular level. These factors are associated principally with alterations in the epigenetic mechanisms that regulate gene expression profiles. Studying the effects of chromatin structure alterations, which are caused by the addition/removal of functional groups to specific histone residues, are of great interest as a promising way to identify markers for cancer diagnosis, classify the disease and determine its prognosis, and these markers could be potential targets for the treatment of this disease in its different forms. This manuscript presents the current point of view regarding members of the recently described family of proteins that exhibit histone demethylase activity; histone demethylases are genetic regulators that play a fundamental role in both the activation and repression of genes and whose expression has been observed to increase in many types of cancer. Some fundamental aspects of their association with the development of cancer and their relevance as potential targets for the development of new therapeutic strategies at the epigenetic level are discussed in the following manuscript.
\end{abstract}

Keywords: neoplasia; epigenomics; histone demethylases; histone demethylases with a jumonji domain 


\section{Introduction}

Cancer is currently recognized as a group of diseases characterized by an abnormal and uncontrolled division of cells, the formation of cellular masses or localized tumors, and the simultaneous formation of independent circulatory and nutrient systems (angiogenesis). Such cells can advance to an invasive-degenerative phenotype in both surrounding and distant tissues through the blood or lymphatic systems via a process known as metastasis, which is the principal cause of death in patients with advanced tumors. Currently, the different types of cancer that affect human beings are considered to be a worldwide public health problem, affecting nearly 13 million people and causing the deaths of eight million people annually [1]. Among the main molecular characteristics that precede the development of this disease are variations in gene expression and genomic instability; these variations are a consequence of disturbances in the processes that regulate protein expression at the genetic and epigenetic levels.

At the functional level, genetic information resides inside the chromatin, which is a structure in the cell nucleus consisting of repetitive units of smaller structures called nucleosomes [2,3]. Nucleosomes consist of 146 base pairs (bp) of DNA wrapped in 1.75 turns around a histone octamer, all of which is organized as a central tetramer of $\mathrm{H} 3 / \mathrm{H} 4$ histones surrounded by two histone $\mathrm{H} 2 \mathrm{~A} / \mathrm{H} 2 \mathrm{~B}$ dimers $[4,5]$. The DNA between nucleosomes can be associated with a fifth histone, H1, to achieve the high-order compression of the chromatin [3,6]. At the structural level, two main chromatin conformations are distinguishable: euchromatin, with a low degree of compression associated with a "relaxed" conformation of the histone-DNA macro-complex, and heterochromatin regions, with a high degree of compression that can be accessory (susceptible to changes in the degree of compression) or constitutive (which is observed during the cell cycle) [3,6]. In epigenetics, variations in the structure or the degree of chromatin compression lead to the regulation of the genes associated with a specific genomic region because these variations facilitate or prevent access of the nuclear proteins required for processes such as gene expression [7]. In this manner, epigenetics regulates the reversible change from heterochromatin (compressed structure associated with the repression of gene expression) to euchromatin (structure accessible to the transcriptional machinery). This regulation occurs via mechanisms that involve DNA methylation and post-translational histone changes such as methylation, citrullination, and ADP-ribosylation of arginine (the latter modification also occurs at glutamic acid residues); methylation, acetylation, biotinylation, ubiquitination, and sumoylation of lysine; phosphorylation of serine and threonine; and the cis-trans isomerization of proline (Figure 1). Each of these modifications has a characteristic effect on the level of gene expression. For example, the addition of acetyl groups to the histones is frequently related to transcriptional activation, whereas deacetylation produces the opposite effect. Conversely, the methylation-demethylation of lysine can be associated with transcriptional activation or repression depending on the function of the residue and the degree of methylation $[8,9]$.

In summary, these processes contribute to a finely regulated mechanism of control of genetic expression and are responsible for maintaining the cellular "equilibrium". In fact, alterations in one or more components of such mechanisms can result in alterations in gene expression and/or cellular phenotype, which are the main causes of the emergence of several pathologies, including neurological diseases, diabetes, and diseases associated with endocrine dysfunction, as well as the different 
varieties of cancer that can affect human beings [10-15]. Consequently, major efforts have been directed toward the identification and characterization of different epigenetic regulators whose phenotypes have been altered in tumor cell lines with the goal of identifying potential therapeutic targets, including DNA-methyltransferases [16-18], histone acetyltransferases/deacetylases [17,19-24], and histone methyltransferases/demethylases [25-29], for the development of more efficient cancer treatment strategies.

Figure 1. Post-translational modifications of histone proteins $\mathrm{H} 1, \mathrm{H} 2 \mathrm{~A}, \mathrm{H} 2 \mathrm{~B}, \mathrm{H} 3$ and $\mathrm{H} 4$ involved in epigenetic regulation. Target amino acids for isomerization ( $\mathbf{\Delta})$, phosphorylation $(\bullet)$, ubiquitination $(\bullet)$, acetylation $(\diamond)$ or methylation $(\square)$ are shown as one-letter code, together with the different enzymes able to add (in blue) each functional group. The histone demethylases are shown in red, besides the lysine residues susceptible to their specific enzymatic activity.

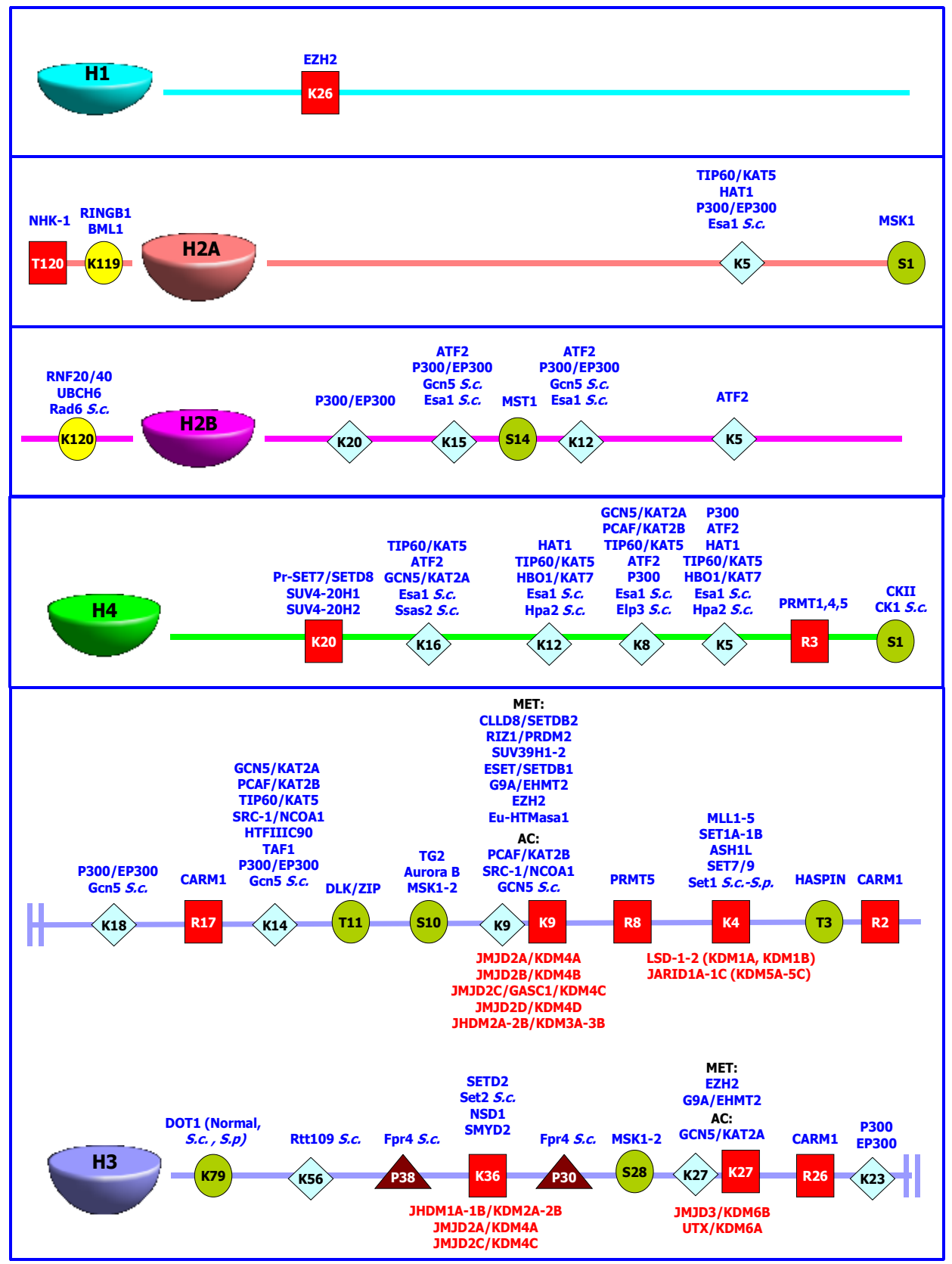


The current work provides an updated description of a large family of histone demethylases that are responsible for maintaining the cellular phenotype by regulating histone methylation levels and serve as promising targets in the development of new treatments against a large variety of forms of cancer. New knowledge will be discussed in relation to the search for new anti-cancer targets, which could be targeted by a new generation of specific drugs directed against these altered histone modifiers.

\section{Connection between Histone Methylation and Disease}

In a large number of cellular processes, covalent modifications induced by methylation can affect different nitrogen-bearing amino acids, such as arginine, histidine, and lysine [30-34]. Histones can be mono-, di-, or tri-methylated at their lysine residues, and they can be mono- or di-methylated at arginine residues in a symmetric or asymmetric fashion (Figure 2).

Figure 2. Methylation patterns of proteins at the lysine and arginine residues. In the histones, it is possible to find (a) mono-, di- and trimethylated forms of lysine, as well as (b) monomethylated and dimethylated forms for arginine.
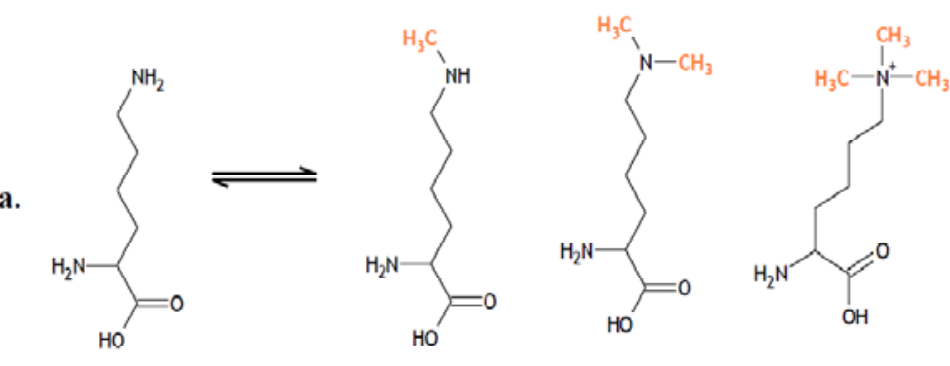

b.
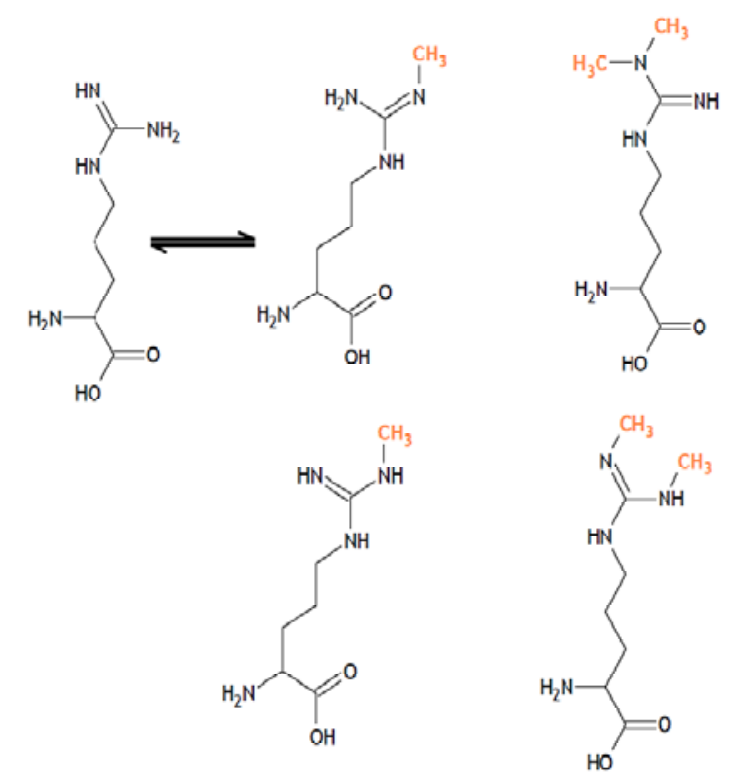

Previously, histone methylation was considered to be a stable and irreversible mark of chromatin [35]. However, in 2004, Shi et al. described the mechanism of action of the first protein with specific demethylase activity against a lysine residue, LSD-1/KDM1A (lysine-specific demethylase-1), breaking the paradigm of irreversible methylation and opening a new research outlook on these proteins and their association with epigenetic regulatory mechanisms [36]. 
The discovery of new sequencing and analysis technologies has allowed for the identification of the histone methylation pattern in the human genome [37], which, in turn, identifies associations between cellular phenotypes and methylation-demethylation as part of regular cell development and in processes related to the emergence of different pathologies. Inside the nucleosome, the $\mathrm{H} 3$ and $\mathrm{H} 4$ histones are the main targets of these modifications, which have been associated with the development of different pathologies, including cancer, that are associated with epigenetic defects (Figures 1 and 3) [38,39]. Such observations have produced significant interest in the characterization of different proteins associated with the epigenetic regulation of histone methylation, among which the recently described histone demethylases are promising targets for future treatments against tumor cells.

Figure 3. Pattern of methylation-demethylation associated with different types of neoplasia. The main alterations at the histone proteins $\mathrm{H} 3$ and $\mathrm{H} 4$ level are illustrated, highlighting the cancers associated with increase (red) or reduction (green) of methylation levels, facing normal cells [39].
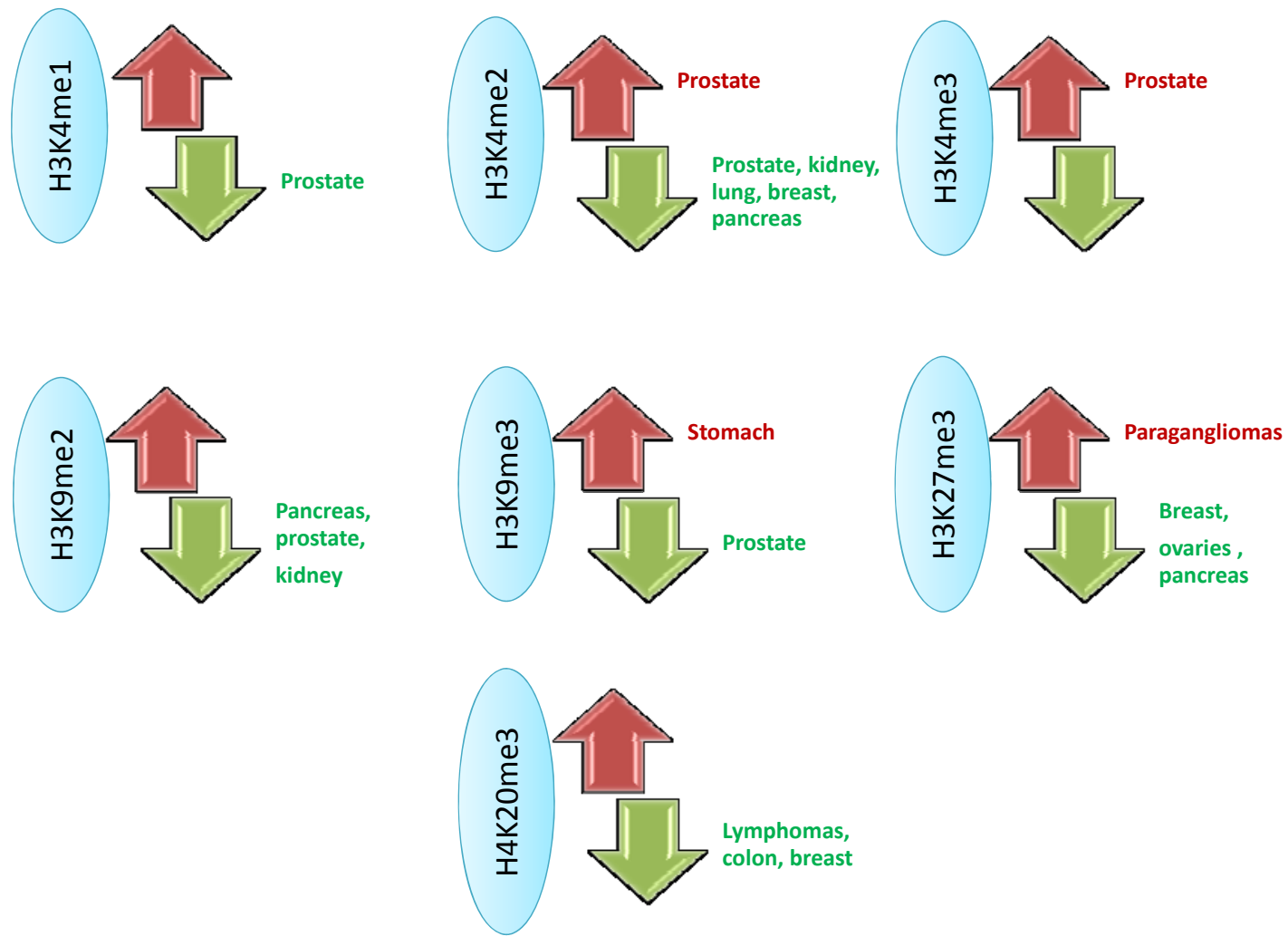

\section{Histone Demethylases and Cancer}

After the first characterization of a protein with demethylase activity, much effort has been made to identify and characterize other proteins with this activity in histone residues. The main proteins that have been discovered to date can be classified into two super-families: those belonging to the amine oxidase superfamily, which are dependent on FAD as a co-factor, and those corresponding to the oxygenase superfamily, in which the demethylase activity is dependent on Fe(II) and $\alpha$-ketoglutarate. This latter superfamily is associated with the presence of a characteristic domain termed Jumonji (Figure 4). Among the most important histone demethylases associated with the development of cancer 
are LSD-1/KDM1A, and members of the Jumonji family JARID1A-1C/KDM5A-5C, JHDM1B/KDM2B, JMJD2C/KDM4C, JMJD2A/KDM4A, JMJD3/KDM6B, and UTX/KDM6A (Table 1), which will be analyzed in detail in the following paragraphs.

Figure 4. Mechanisms of histone demethylation [40]. (a) The proteins having an amine-oxidase FAD-dependent activity require at least one atom of hydrogen on the lysine's amine group, implying these proteins' activity on the mono- and dimethylated forms of this amino acid. On the other hand, those proteins with oxygenase activity (b) are able to add a hydroxyl group to the methyl group, in a $\mathrm{Fe}^{2+}$ - and $\alpha$-ketoglutarate dependent way, letting them act on the quaternary form of the methylated amine.

a.

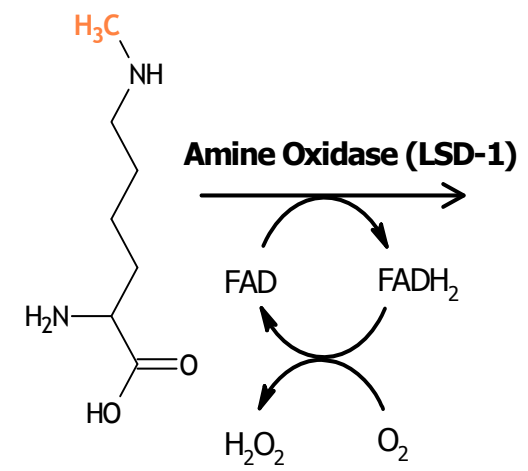

b.<smiles>C[N+](C)(C)CCCCC(N)C(=O)O</smiles>
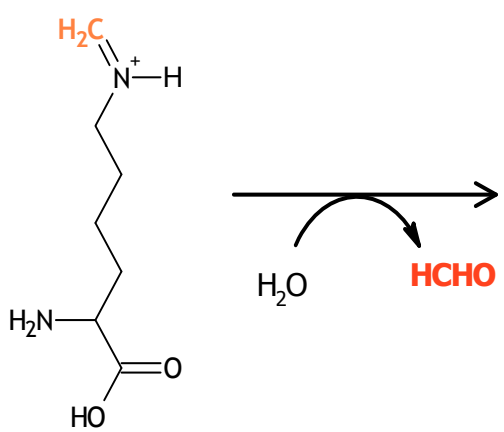
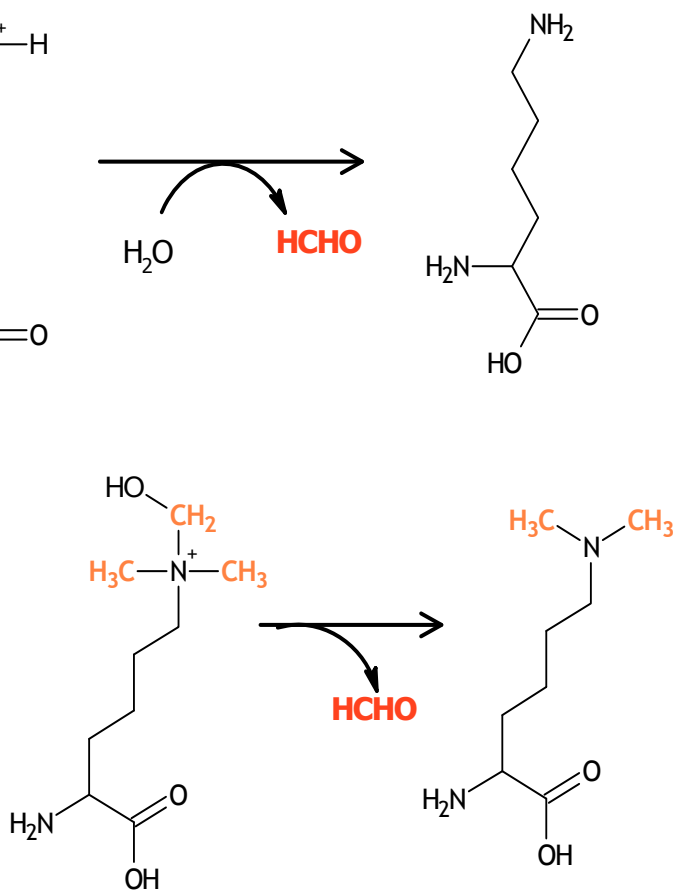

Table 1. Histone demethylases and their association with cancer development.

\begin{tabular}{|c|c|c|l|c|}
\hline $\begin{array}{c}\text { Histone } \\
\text { demethylase }\end{array}$ & $\begin{array}{c}\text { Genebank Acc. } \\
\text { Number }\end{array}$ & Alteration & \multicolumn{1}{|c|}{ Associated cancer } & References \\
\hline \multirow{2}{*}{ LSD-1/KDM1A } & NM_015013 & $\begin{array}{c}\text { Over- } \\
\text { expression }\end{array}$ & $\begin{array}{l}\text { ER-negative breast, Prostate, Leukemia, } \\
\text { Sarcomas, Lung, neuroblastoma }\end{array}$ & {$[31,41-49]$} \\
\cline { 3 - 5 } & $\begin{array}{c}\text { Low } \\
\text { expression }\end{array}$ & $\begin{array}{l}\text { Hepatocellular, gastrointestinal, } \\
\text { Hepatobiliary and metastatic breast } \\
\text { carcinomas }\end{array}$ & {$[50,51]$} \\
\hline JARID1A/KDM5A & NM_001042603 & $\begin{array}{c}\text { Over- } \\
\text { expression }\end{array}$ & Gastric, Leukemia & {$[52,53]$} \\
\hline JARID1B/KDM5B & NM_006618 & $\begin{array}{c}\text { Over- } \\
\text { expression }\end{array}$ & $\begin{array}{l}\text { Testicular, Ovaries, Breast, Prostate, } \\
\text { leukemia }\end{array}$ & {$[54-61]$} \\
\hline JARID1C/KDM5C & $\begin{array}{c}\text { NM_004187.3 } \\
\text { NM_001146702.1 }\end{array}$ & $\begin{array}{c}\text { Over- } \\
\text { expression }\end{array}$ & Renal Carcinoma, Cervical & {$[62-64]$} \\
\hline
\end{tabular}


Table 1. Cont.

\begin{tabular}{|c|c|c|c|c|}
\hline Histone demethylase & $\begin{array}{l}\text { Genebank Acc. } \\
\text { Number. }\end{array}$ & Alteration & Associated cancer & References \\
\hline \multirow{2}{*}{ JHDM1B/FBXL10/KDM2B } & \multirow{2}{*}{ NM_032590 } & $\begin{array}{l}\text { Over-expression/ } \\
\text { Mutation }\end{array}$ & $\begin{array}{l}\text { Lymphomas, Acute } \\
\text { myeloid leukemia }\end{array}$ & [65-67] \\
\hline & & Low expression & $\begin{array}{l}\text { Gliobastoma multiforme, } \\
\text { brain }\end{array}$ & [68] \\
\hline $\mathrm{JMJD} 2 \mathrm{C} / \mathrm{KDM} 4 \mathrm{C}$ & $\begin{array}{l}\text { NM_015061; } \\
\text { NM_001146694; } \\
\text { NM_001146695; } \\
\text { NM_001146696 }\end{array}$ & Over-expression & $\begin{array}{l}\text { MALT and Hodgkin } \\
\text { Lymphomas, myeloid } \\
\text { leukemia, Breast, } \\
\text { gliobastoma multiforme, } \\
\text { prostate, desmoplasic } \\
\text { meduloblastoma, } \\
\text { sarcomatoid and } \\
\text { esophageal carcinoma. }\end{array}$ & [69-82] \\
\hline JMJD2A/KDM4A & NM_014663 & Over-expression & $\begin{array}{l}\text { Kaposi Sarcoma, } \\
\text { Prostate, Breast, Colon, } \\
\text { Bladder. }\end{array}$ & $\begin{array}{c}{[18,47,83-} \\
87]\end{array}$ \\
\hline JMJD3/KDM6B & NM_001080424 & Over-expression & Colon, Lymphomas & [88-90] \\
\hline UTX/KDM6A & NM_021140 & $\begin{array}{l}\text { Mutation/Low } \\
\text { expression }\end{array}$ & $\begin{array}{l}\text { Advanced forms of } \\
\text { cancer, Multiple } \\
\text { mieloma, Leukemia, } \\
\text { renal and bladder } \\
\text { carcinomas. }\end{array}$ & [91-96] \\
\hline
\end{tabular}

\subsection{LSD-1 and LSD-2}

The LSD-1/KDM1A protein was the first demethylase protein to be identified [36]. In the monoand bi-methylated forms, this amine oxidase presents specific activity on lysine 4 of histone $\mathrm{H} 3$ and forms part of an important macromolecular complex: CoREST [97-99]. LSD-1 is considered to be an important regulator of the formation and development of organs and tissues such as the heart, brain and skeletal muscle [100-103], together its essential role for cellular energy expenditure, inflammatory responses and hematopoiesis [104-106]. Interestingly, it has been reported that in the prostate, this enzyme can change its substrate to the mono-methylated form of lysine 9 as a result of its association with another important histone demethylase, JMJD2C. Together, both proteins have been associated with the development of prostate and bladder cancer through putative interactions with androgen receptors $[41,43,47,48]$. Additionally, the activity and overexpression of LSD-1 have been related to the emergence and development of different types of cancer, such as neuroblastoma [49], leukemia [31,42], sarcoma [44], lung [45], and ER-negative breast cancer [46]. In contrast, low levels of this protein have been observed in hepatocellular, gastrointestinal, hepatobiliary and metastatic breast carcinomas [50,51]. On the other hand, the understanding of molecular mechanisms ruling LSD-1 activity is in continuous evolution since its 3D structure determination [107], leading to the rational discovering of promising 
inhibitors with therapeutic potential [67,108-111]. Interactions based on these studies, LSD-1 is thought to be a potential marker for the early diagnosis and potential treatment of the malignant tumors mentioned above [112].

In addition, it has been recently described a new member of amine oxidase protein family: LSD-2/AOF1/KDM1B. Although this protein is homologous to LSD-1, it doesn't participate in the chromatin-remodeling complexes as LSD-1 does [113,114]. This demethylase (showing specific activity for mono- and di-methylated Lys4 of histone H3) has been associated with the regulation of the inflammatory process mediated by $\mathrm{NF}-\kappa \mathrm{B}$ [115] and for establishing the maternal genomic imprints [116], as well as LSD-2 represents an important factor for induced pluripotent stem cell generation [117]. Although it has not been reported of any association for LSD-2 with human pathologies, the importance of its demethylase activity and LSD-1's important as an anti-cancer candidate highlight the importance of continuing the functional and structural characterization of this protein $[99,114,118]$.

\subsection{JARID1 Family}

Members of the JARID1 family of oxygenases recognize and act specifically on the bi- and tri-methylated lysine 4 of histone $\mathrm{H} 3$. One of the most representative members of this family is JARID1A/RBP2/KDM5A, which is an important regulator of the circadian rhythm $[119,120]$. This enzyme is also involved in cell cycle regulation [121] because it interacts with important proteins such as the retinoblastoma protein, and it is thought to affect pathways that are dependent on cyclins in some cancer types such as gastric cancer [52] and leukemia [53], as well as has been considered as a relevant marker to evaluate gliobastoma multiform survival [122]. Interestingly, it has been reported JARID1A is a critical factor for the development of transient drug tolerance in lung cancer cells [123], representing a key target to analyze how non-heritable aspects of cellular variability may significantly affect the evolutionary rate of cancer, in such way that initial drug treatments may be driving tumors to establish a genetically-based resistance by first selecting these non-heritable phenotypes generated by cellular or tissue variability [124]. On the other hand, the relevance of this protein has also been described in the emergence of other diseases including ankylosing spondylitis [125] and alopecia areata [126]. However, the current knowledge of the function of this protein at the cellular level is limited, although a role for this protein as a regulator of cellular growth via the Notch signaling pathway has been proposed [127], as well as it has been reported JARID1A and JARID1B are associated to the silencing of retinoblastoma target genes in senescent cells [128].

The second member of this family, JARID1B/PLU1/KDM5B has been recognized to be an important regulator of cell development and differentiation [129-132]. This enzyme has been strongly connected with the formation of different types of cancer because of the high expression levels found in leukemia, prostate, breast, testicular, and ovarian cancers, in which it can act as a repressor of tumor suppressor genes including BRCA1 or as a coactivator of growth and transcription factors such as TIEG1/KLF10 or the androgen receptor [54-61]. In summary, these results have fueled the search for inhibitors with anticarcinogenic potential directed against this protein [133].

Additionally, the third member of this protein family (JARID1C/KDM5C) is an important mediator during intellectual and cognitive development [134,135], and multiple defects in this protein have been 
associated with different pathologies including intellectual disability (mental retardation), short height, delay in speech abilities, and autism [135-139]. Similar to the other members of this family of proteins, JARID1C represents an interesting therapeutic target in the search for new drugs [140] because of its relevance and recent association with the development of renal carcinomas via the regulation of the von Hippel-Lindau tumor suppressor protein $[62,64]$ and because of its implication in cervical cancer by serving as an oncogenic target of the human papillomavirus [63].

\subsection{JHDM1B}

JHDM1B/KDM2B, a member of the Jumonji protein family, exhibits oxygenase activity at the mono- and bi-methylated lysine 36 of histone H3. Although a role for this protein has not been defined at the cellular level, recent studies suggest a relationship between this methylase and important processes such as the regulation of cell proliferation and senescence [141,142] and the possible application of this protein as an enhancer in the reprogramming of stem cells [143]. Currently, this protein is considered to be a candidate tumor suppressor gene because its expression levels are strongly reduced in different forms of cancer, including acute myeloid leukemia, lymphoma, and glioblastoma multiforme, the most aggressive form of brain cancer [65-68,144,145].

\subsection{JMJD2C}

JMJD2C/KDM4C is a histone demethylase that exhibits oxygenase activity at the bi- and tri-methylated lysine 9 in histone H3 [69], and this protein is involved in the development and self-renewal of undifferentiated and embryonic stem cells, the regulation of adipogenesis, and hypoxia responses [146-149]. In addition to these functions, JMJD2C has been associated with the emergence of different pathologies such as alopecia areata and autistic spectrum disorders [126,150]. It is also considered to be an important amplified oncogene in different types of cancer such as sarcomatoid and esophageal carcinomas [70,82], myeloid leukemia [71,72], lymphoma [73,74,80], breast carcinoma [75,76], desmoplastic medulloblastoma [81], and glioblastoma multiforme [77,78]. Although the mechanisms by which this protein is involved in the development of these types of cancer have not been fully understood, the characteristics of this protein have suggested JMJD2C as a potential candidate for the development of specific treatments against these forms of cancer [25,110,151].

\subsection{JMJD2A}

JMJD2A/KDM4A, another member of the Jumonji protein family, is associated with the transcription of cell proliferation genes due to its capacity to bind to chromatin-modifying and cell cycle regulator proteins [152]. After the establishment of its methylase activity on bi- and tri-methylated lysines 9 and 36 of histone H3 [153], JMJD2A has been shown to play important roles in skeletal muscle cell and neural crest differentiation, the maintenance of maternal stem cells, and DNA repair [148,154,155]. This protein is related to the development of diseases such as cardiac hypertrophy [156], alopecia areata [126], and different forms of cancer including Kaposi's sarcoma associated with herpesvirus [85], prostate cancer (via regulation of the activity of the androgen receptor) [83,84], breast cancer [86], colon cancer [87], and bladder cancer [47]. Such results highlight 
the relevance of this protein at the therapeutic level, and have arised the interest to determine JMJD2A's mechanism of action and specificity based on its three-dimensional structure [157-161]. This strategy may lead to the identification and characterization of specific inhibitors with therapeutic potentials $[25,151,162,163]$. However, knowledge of the function of JMJD2A in other carcinogenic lines and the determination of its role as a therapeutic anti-cancer target still remain to be established.

\subsection{JMJD3}

JMJD3/KDM6B, another member of the Jumonji family, exhibits high specificity for the bi- and tri-methylated lysine 27 residue of histone H3 [164], and it serves as a part of important multiprotein complexes known as MLL3 and MLL4, which are associated with the regulation of the activity of Polycomb family proteins [165-169]. Such characteristics have promoted the investigation of the relevance of this protein at the cellular level, allowing for its identification as a regulator in endothelial, endodermal, osteoclast, macrophage, and neural lineage differentiation [170-174]. Additionally, the influence of this enzyme on the occurrence of a large number of diseases has been described, with implications in systemic lupus erythematosus [175], vasculitis associated with antineutrophil cytoplasmic antibodies (ANCA) [176], colon cancer [90], and lymphoma [88,89]. Although the role of this protein in these pathologies has not been fully described, JMJD3 is associated with the activity of different oncogenes such as NPM-ALK and BCL2, or tumor-suppressing genes such as BTG3 [89,177,178]; justifying the inclusion of this protein in the search for new anti-cancer epidrugs [179].

\subsection{UTX}

Similarly to JMJD3, UTX/KDM6A acts on the mono- and di-methylated forms of lysine 27 in histone H3 [180] and is also a part of the MLL3/MLL4 complexes [166,167]. UTX was the first histone demethylase known to be associated with cancer as a result of specific mutations [96]. In combination with the relevance of UTX in cellular differentiation at the cardiac, hematopoietic, sperm, brain, and muscular levels [135,181-184], this enzyme is also a tumor suppressor gene candidate (like JHDM1B). This designation was the result of multiple investigations that identified mutations or inactivating events associated with the differentiation of tumor cells in multiple myeloma [94,96], acute lymphoblastic and chronic myelomonocytic leukemias [93,95], bladder carcinoma [92], and renal cell carcinoma [91]. Similarly to JARID1A, UTX has been recently linked to regulation processes that are dependent on the retinoblastoma protein, as it is primarily associated with control of the expression of different factors that are part of the pathways that are dependent on this important enzyme [185,186]; this activity is related to the potential role of this protein as a tumor suppressor [187].

\section{Therapeutic Approaches}

Recently, an indirect or direct association has been established between histone demethylases and the emergence and progression of cancer. Among the potential strategy for targeting KDMs, the identification of molecules with the capacity to specifically inhibit the enzymatic activity of these proteins represents a promising path for treatment [10,188]. As the first member of this important family of proteins, LSD-1 represents an important target for the so-called "epi-drugs". Among the 
molecules with pharmaceutical potential are oligoamine analogs, originally designed based on the significant similarity between LSD-1 and other FAD-dependent polyamine oxidases (Figure 5a, top panel) [109,189], and specific inhibitors possessing a common 2-phenyl cyclopropyl-1-amine nucleus [108,118,190,191]. These specific inhibitors for LSD-1 were designed based on the mechanism of action of the enzyme (which is similar to that of monoamine oxidases), and are able to reach inhibition constants in the micromolar range (Figure 5a, lower panel) $[108,118,190,191]$.

Figure 5. Inhibitors of histone demethylation. Specific inhibitors for LSD1 can be designed according to the similarity of this demethylase's substrates with the FAD-dependent polyamine oxidases targets (a, top frame), as can be observed for spermidin-like inhibitors, octamines $(n=3)$ or decamines $(n=4)$. Another pathway for designing amine oxidases' inhibitors involves their mechanism of activity, targeting FAD by radical oxidation reactions with "suicide" inhibitors containing a phenylcyclopropylamine core (a, bottom frame). Histone demethylases with oxygenase activity can be inhibited by using $\alpha$-ketoglutarate analogues, as these could be able to bind to $\mathrm{Fe}^{2+}$. Some of the most promising epidrugs includes some derivatives of $N$-oxalyl glucose and $N$-oxalyl tyrosine, (b, top frame), in conjuction with the recent description of flavonoids and chatecols showing competitive and non-competitive inhibition, possibly associated with these natural product's ability to bind iron (b, bottom frame).
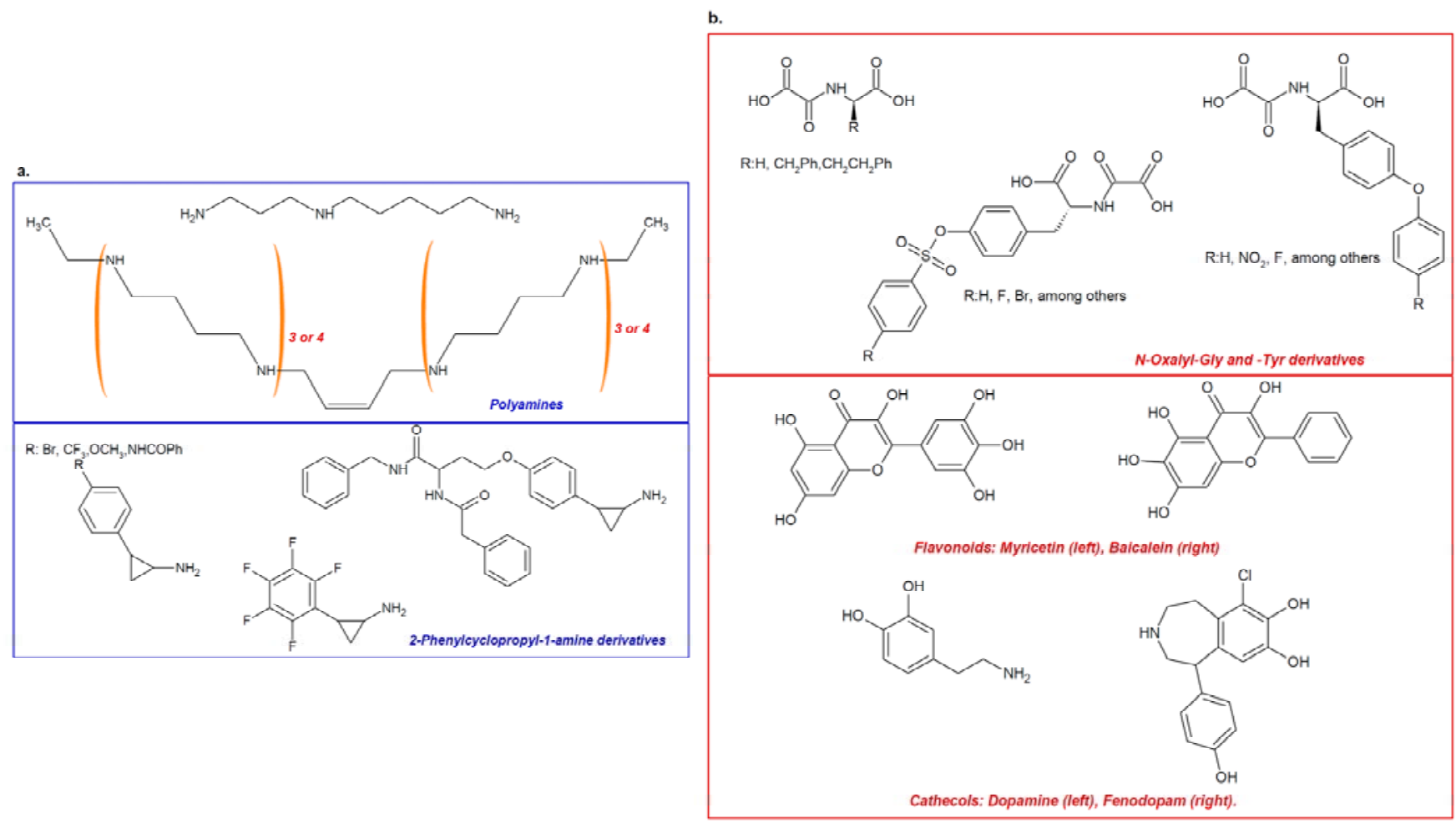

These findings have promoted the search for new inhibitors and have resulted in the recent description of namoline, a gamma-pyrone capable of inhibiting LSD-1 and altering the growth of prostate cancer tumor cells [192]. The first generation of LSD-1 inhibitors, which are of the tranylcypromine type, exhibited low potency and selectivity. After the search was shifted to focus on chemical structures that target the active site of the protein, selectivity was increased [193]. In vitro 
and in vivo studies using nanomolar concentrations of phenocopied, a tranylcypromine analog and inhibitor of LSD-1, demonstrated a pro-apoptotic effect in primary acute myeloid leukemia (AML) cells without affecting the repopulation potential of hematopoietic stem cells and progenitor cells [194]. These data suggest that LSD-1 is a key protein for the development of selective therapeutic targets for leukemia.

In the same manner, the inhibition of LSD-1 can increase the sensitivity of promyelocytic leukemia (APL) to the treatment with all-trans-retinoic acid (ATRA). Usually ATRA loses its activity in APL, and the cause of this alteration appears to be a reduction in the methylation of lysine 4 of histone H3. Under such conditions, the inhibition of LSD-1 can facilitate the activity of ATRA in APL cells, as it has been validated using the LSD-1 inhibitor trans-2-phenylcyclopropylamine [195].

In addition, iron- and $\alpha$-ketoglutarate-dependent histone demethylases are also targets of important studies, allowing for the identification of inhibitors designed on the basis of the mechanism of the unique activity of these enzymes. Among the most important inhibitors, several molecules that are analogous to $\alpha$-ketoglutarate have been described. These inhibitors range from molecules designed using $N$-oxalylglycine or $N$-oxalyltyrosine as a base molecule $[25,162,196]$ (Figure 5 b, upper panel) to natural products such as flavonoids and catechols that were identified as a result of screening libraries of pharmacologically active compounds [197] (Figure 5b, lower panel). Demethylase inhibitors for Jumonji-containing domain proteins usually compete with the 2-oxoglutarate factor and bind to the catalytic region containing iron. Compounds that possess high polarity, such as 2,4-pyridine-decarboxylases, inhibit the activity of Jumonji by interfering with its enzymatic activity, in the same way other 2-oxoglutarate-like molecules inhibit the HIF prolyl hydroxylase-1 oxygenases HPH1/EGLN2 and HPH2/EGLN1.Interestingly, two new series of jumonji demethylase inhibitors, 8-hydroxyquinolines (e.g., SID 85736331) and 2,2-bipyridines, are potent inhibitors with higher selectivity and better pharmacological properties than those exhibited by other inhibitors. The structures of these two new types of compounds make them promising therapeutic alternatives that could be pharmacologically enhanced for better penetration into the cell interior [198,199].

These results clearly highlight the potential of the histone demethylase superfamily members as therapeutic targets against the diverse neoplastic diseases that affect human beings. There is support for structural analyses to increase the understanding of the spatial enzyme-inhibitor interaction $[99,200,201]$ and, hence, promote the specific molecular design of a new generation of epi-drugs targeting members of the amine oxidase superfamily $[108,202,203]$ or those belonging to the oxygenase family $[25,159,162]$.

\section{Conclusions}

Regulation of gene expression encompasses a complex network of molecular interactions that define the cellular phenotype of tissues and organisms. Alteration on the epigenetic balance can result in the emergence of terminal diseases, among which are the several forms of human cancer. Although, much work remains to be taken in the search for new strategies against the different types of cancer, in recent years, significant advances have been made in the identification and characterization of new potential targets for the development of specific therapies to treat multiple forms of cancer. Together with the continuous discovering of new macromolecules associated with human neoplasm, the recent discovery of histone demethylases has provided a new perspective in the search for anti-cancer 
therapeutic targets due to their unique enzymatic activity and their association with the cellular phenotype of a large number of human tumor lines.

Either as early markers or as anti-tumor candidates, histone demethylases currently represent a promising group of macromolecules that increase our understanding of malignity and the mysteries of their formation, development and evolutionary progress. LSD1 was the first demethylases cloned and perhaps the most promises protein as therapeutic target. Recently evidences showed that LSD1 played an important role in a broad spectrum of biological processes, including cell proliferation, adipogenesis, spermatogenesis, chromosome segregation and embryonic development. Furthermore, LSD1 also could promote progress of tumor by inhibiting the tumor suppressor activity of p53. To date, as a potential drug for discovering anti-tumor drugs, the medical significance of LSD1 inhibitors have been greatly appreciated. However, it is necessary to be attentive when analyzing and applying this new knowledge, as relevant targets as LSD-1 could be observed as an oncogene [31,41-49] or a tumor-suppressor [50,51], in an apparent situation-dependent biological role for this protein. These observations, enhanced the importance of histone demethylases for cellular and tissue phenotype maintenance as part of macro-complexes [51,114,127,152,169], must be taken into account to overcome any side effects facing their use as therapeutic targets [106]; thus highlighting the importance of improving our comprehension about biological and molecular role of histone demethylases, to be established as potential targets for a new generation of epigenetic drugs directed against their enzymatic activity. Various demethylases from Jumonji family are in preclinical studies for cancer including prostate cancer, glioblastoma, breast cancer, and diverse kind of leukemia.

In summary, this report is part of the future on the continuous fight against cancer; searching for new specific therapeutic strategies based on the understanding of the epigenetic regulators discussed herein and those different molecules rationally designed against these specific targets; the epi-drugs.

\section{Acknowledgments}

We would like to thank Colciencias and La Universidad de La Sabana that are supporting the research in histone demethylases field with the grant No. 528 from Colciencias, and the grant No. 909 from La Universidad de la Sabana.

\section{Conflict of Interest}

The authors declare no conflict of interest.

\section{References}

1. World Health Organization. WHO World Cancer Report 2008; WHO: Geneva, Switzerland, 2008.

2. Kornberg, R.D. Chromatin structure: A repeating unit of histones and DNA. Science 1974, 184, 868-871.

3. Li, G.; Reinberg, D. Chromatin higher-order structures and gene regulation. Curr. Opin. Genet. Dev. 2011, 21, 175-186.

4. Luger, K.; Mader, A.W.; Richmond, R.K.; Sargent, D.F.; Richmond, T.J. Crystal structure of the nucleosome core particle at 2.8 A resolution. Nature 1997, 389, 251-260. 
5. Xu, M.; Zhu, B. Nucleosome assembly and epigenetic inheritance. Protein Cell 2010, 1, 820-829.

6. Chen, P.; Li, G. Dynamics of the higher-order structure of chromatin. Protein Cell 2010, 1, 967-971.

7. Bassett, A.; Cooper, S.; Wu, C.; Travers, A. The folding and unfolding of eukaryotic chromatin. Curr. Opin. Genet. Dev. 2009, 19, 159-165.

8. Berger, S.L. The complex language of chromatin regulation during transcription. Nature 2007, 447, 407-412.

9. Latham, J.A.; Dent, S.Y. Cross-regulation of histone modifications. Nat. Struct. Mol. Biol. 2007, 14, 1017-1024.

10. Arrowsmith, C.H.; Bountra, C.; Fish, P.V.; Lee, K.; Schapira, M. Epigenetic protein families: A new frontier for drug discovery. Nat. Rev. Drug Discov. 2012, 11, 384-400.

11. Bayarsaihan, D. Epigenetic mechanisms in inflammation. J. Dent. Res. 2011, 90, 9-17.

12. Hamm, C.A.; Costa, F.F. The impact of epigenomics on future drug design and new therapies. Drug Discov. Today 2011, 16, 626-635.

13. Tsai, H.C.; Baylin, S.B. Cancer epigenetics: Linking basic biology to clinical medicine. Cell Res. 2011, 21, 502-517.

14. Zahir, F.R.; Brown, C.J. Epigenetic impacts on neurodevelopment: Pathophysiological mechanisms and genetic modes of action. Pediatr. Res. 2011, 69, 92R-100R.

15. Zhang, X.; Ho, S.M. Epigenetics meets endocrinology. J. Mol. Endocrinol. 2011, 46, R11-R32.

16. Castellano, S.; Kuck, D.; Viviano, M.; Yoo, J.; Lopez-Vallejo, F.; Conti, P.; Tamborini, L.; Pinto, A.; Medina-Franco, J.L.; Sbardella, G. Synthesis and biochemical evaluation of delta(2)-isoxazoline derivatives as DNA methyltransferase 1 inhibitors. J. Med. Chem. 2011, 54, 7663-7677.

17. Yi, T.Z.; Li, J.; Han, X.; Guo, J.; Qu, Q.; Guo, L.; Sun, H.D.; Tan, W.H. DNMT Inhibitors and HDAC Inhibitors Regulate E-Cadherin and Bcl-2 Expression in Endometrial Carcinoma in vitro and in vivo. Chemotherapy 2012, 58, 19-29.

18. Chen, M.; Shabashvili, D.; Nawab, A.; Yang, S.X.; Dyer, L.M.; Brown, K.D.; Hollingshead, M.; Hunter, K.W.; Kaye, F.J.; Hochwald, S.N.; et al. DNA methyltransferase inhibitor, zebularine, delays tumor growth and induces apoptosis in a genetically engineered mouse model of breast cancer. Mol. Cancer Ther. 2012, 11, 370-382.

19. Ahmad, M.; Hamid, A.; Hussain, A.; Majeed, R.; Qurishi, Y.; Bhat, J.A.; Najar, R.A.; Qazi, A.K.; Zargar, M.A.; Singh, S.K.; et al. Understanding histone deacetylases in the cancer development and treatment: An epigenetic perspective of cancer chemotherapy. DNA Cell Biol. 2012, doi:10.1089/dna.2011.1575.

20. Mehdi, O.; Francoise, S.; Sofia, C.L.; Urs, G.; Kevin, Z.; Bernard, S.; Igor, S.; Anabela, C.D.; Dominique, L.; Eric, M.; Ali, O. HDAC gene expression in pancreatic tumor cell lines following treatment with the HDAC inhibitors panobinostat (LBH589) and trichostatine (TSA). Pancreatology 2012, 12, 146-155.

21. Munster, P.N.; Thurn, K.T.; Thomas, S.; Raha, P.; Lacevic, M.; Miller, A.; Melisko, M.; Ismail-Khan, R.; Rugo, H.; Moasser, M.; et al. A phase II study of the histone deacetylase inhibitor vorinostat combined with tamoxifen for the treatment of patients with hormone therapy-resistant breast cancer. Br. J. Cancer 2011, 104, 1828-1835. 
22. Oike, T.; Ogiwara, H.; Torikai, K.; Nakano, T.; Yokota, J.; Kohno, T. Garcinol, a histone acetyltransferase inhibitor, radiosensitizes cancer cells by inhibiting non-homologous end joining. Int. J. Radiat. Oncol. Biol. Phys. 2012, in press.

23. Thurn, K.T.; Thomas, S.; Moore, A.; Munster, P.N. Rational therapeutic combinations with histone deacetylase inhibitors for the treatment of cancer. Future Oncol. 2011, 7, 263-283.

24. Uehara, N.; Yoshizawa, K.; Tsubura, A. Vorinostat enhances protein stability of p27 and p21 through negative regulation of Skp2 and Cks1 in human breast cancer cells. Oncol. Rep. 2012, 28, 105-110.

25. Hamada, S.; Suzuki, T.; Mino, K.; Koseki, K.; Oehme, F.; Flamme, I.; Ozasa, H.; Itoh, Y.; Ogasawara, D.; Komaarashi, H.; et al. Design, synthesis, enzyme-inhibitory activity, and effect on human cancer cells of a novel series of jumonji domain-containing protein 2 histone demethylase inhibitors. J. Med. Chem. 2010, 53, 5629-5638.

26. Rao, M.; Chinnasamy, N.; Hong, J.A.; Zhang, Y.; Zhang, M.; Xi, S.; Liu, F.; Marquez, V.E.; Morgan, R.A.; Schrump, D.S. Inhibition of histone lysine methylation enhances cancer-testis antigen expression in lung cancer cells: Implications for adoptive immunotherapy of cancer. Cancer Res. 2011, 71, 4192-4204.

27. Toyokawa, G.; Cho, H.S.; Iwai, Y.; Yoshimatsu, M.; Takawa, M.; Hayami, S.; Maejima, K.; Shimizu, N.; Tanaka, H.; Tsunoda, T.; et al. The histone demethylase JMJD2B plays an essential role in human carcinogenesis through positive regulation of cyclin-dependent kinase 6. Cancer Prev. Res. (Phila.) 2011, 4, 2051-2061.

28. Toyokawa, G.; Cho, H.S.; Masuda, K.; Yamane, Y.; Yoshimatsu, M.; Hayami, S.; Takawa, M.; Iwai, Y.; Daigo, Y.; Tsuchiya, E.; et al. Histone lysine methyltransferase Wolf-Hirschhorn syndrome candidate 1 is involved in human carcinogenesis through regulation of the Wnt pathway. Neoplasia 2011, 13, 887-898.

29. Wang, J.; Lu, F.; Ren, Q.; Sun, H.; Xu, Z.; Lan, R.; Liu, Y.; Ward, D.; Quan, J.; Ye, T.; et al. Novel histone demethylase LSD1 inhibitors selectively target cancer cells with pluripotent stem cell properties. Cancer Res. 2011, 71, 7238-7249.

30. Chen, X.; Hu, Y.; Zhou, D.X. Epigenetic gene regulation by plant Jumonji group of histone demethylase. Biochim. Biophys. Acta 2011, 1809, 421-426.

31. Li, Y.; Deng, C.; Hu, X.; Patel, B.; Fu, X.; Qiu, Y.; Brand, M.; Zhao, K.; Huang, S. Dynamic interaction between TAL1 oncoprotein and LSD1 regulates TAL1 function in hematopoiesis and leukemogenesis. Oncogene 2012, doi:10.1038/onc.2012.8.

32. Rodova, M.; Lu, Q.; Li, Y.; Woodbury, B.G.; Crist, J.D.; Gardner, B.M.; Yost, J.G.; Zhong, X.B.; Anderson, H.C.; Wang, J. Nfat1 regulates adult articular chondrocyte function through its age-dependent expression mediated by epigenetic histone methylation. J. Bone Miner. Res. 2011, 26, 1974-1986.

33. Ura, H.; Murakami, K.; Akagi, T.; Kinoshita, K.; Yamaguchi, S.; Masui, S.; Niwa, H.; Koide, H.; Yokota, T. Eed/Sox2 regulatory loop controls ES cell self-renewal through histone methylation and acetylation. EMBO J. 2011, 30, 2190-2204.

34. Vicent, G.P.; Nacht, A.S.; Font-Mateu, J.; Castellano, G.; Gaveglia, L.; Ballare, C.; Beato, M. Four enzymes cooperate to displace histone H1 during the first minute of hormonal gene activation. Genes Dev. 2011, 25, 845-862. 
35. Bannister, A.J.; Schneider, R.; Kouzarides, T. Histone methylation: Dynamic or static? Cell 2002, 109, 801-806.

36. Shi, Y.; Lan, F.; Matson, C.; Mulligan, P.; Whetstine, J.R.; Cole, P.A.; Casero, R.A. Histone demethylation mediated by the nuclear amine oxidase homolog LSD1. Cell 2004, 119, 941-953.

37. Barski, A.; Cuddapah, S.; Cui, K.; Roh, T.Y.; Schones, D.E.; Wang, Z.; Wei, G.; Chepelev, I.; Zhao, K. High-resolution profiling of histone methylations in the human genome. Cell 2007, $129,823-837$.

38. Rotili, D.; Mai, A. Targeting histone demethylases: A new avenue for the fight against cancer. Genes Cancer 2011, 2, 663-679.

39. Varier, R.A.; Timmers, H.T. Histone lysine methylation and demethylation pathways in cancer. Biochim. Biophys. Acta 2011, 1815, 75-89.

40. Hou, H.; Yu, H. Structural insights into histone lysine demethylation. Curr. Opin. Struct. Biol. 2010, 20, 739-748.

41. Kahl, P.; Gullotti, L.; Heukamp, L.C.; Wolf, S.; Friedrichs, N.; Vorreuther, R.; Solleder, G.; Bastian, P.J.; Ellinger, J.; Metzger, E.; et al. Androgen receptor coactivators lysine-specific histone demethylase 1 and four and a half LIM domain protein 2 predict risk of prostate cancer recurrence. Cancer Res. 2006, 66, 11341-11347.

42. Harris, W.J.; Huang, X.; Lynch, J.T.; Spencer, G.J.; Hitchin, J.R.; Li, Y.; Ciceri, F.; Blaser, J.G.; Greystoke, B.F.; Jordan, A.M.; et al. The Histone demethylase KDM1A sustains the oncogenic potential of MLL-AF9 leukemia stem cells. Cancer Cell 2012, 21, 473-487.

43. Wissmann, M.; Yin, N.; Muller, J.M.; Greschik, H.; Fodor, B.D.; Jenuwein, T.; Vogler, C.; Schneider, R.; Gunther, T.; Buettner, R.; et al. Cooperative demethylation by JMJD2C and LSD1 promotes androgen receptor-dependent gene expression. Nat. Cell Biol. 2007, 9, 347-353.

44. Bennani-Baiti, I.M.; Machado, I.; Llombart-Bosch, A.; Kovar, H. Lysine-specific demethylase 1 (LSD1/KDM1A/AOF2/BHC110) is expressed and is an epigenetic drug target in chondrosarcoma, Ewing's sarcoma, osteosarcoma, and rhabdomyosarcoma. Hum. Pathol. 2012, 43, 1300-1307.

45. Lv, T.; Yuan, D.; Miao, X.; Lv, Y.; Zhan, P.; Shen, X.; Song, Y. Over-expression of LSD1 promotes proliferation, migration and invasion in non-small cell lung cancer. PLoS One 2012, 7, e35065.

46. Lim, S.; Janzer, A.; Becker, A.; Zimmer, A.; Schule, R.; Buettner, R.; Kirfel, J. Lysine-specific demethylase 1 (LSD1) is highly expressed in ER-negative breast cancers and a biomarker predicting aggressive biology. Carcinogenesis 2010, 31, 512-520.

47. Kauffman, E.C.; Robinson, B.D.; Downes, M.J.; Powell, L.G.; Lee, M.M.; Scherr, D.S.; Gudas, L.J.; Mongan, N.P. Role of androgen receptor and associated lysine-demethylase coregulators, LSD1 and JMJD2A, in localized and advanced human bladder cancer. Mol. Carcinog. 2011, 50, 931-944.

48. Metzger, E.; Wissmann, M.; Yin, N.; Muller, J.M.; Schneider, R.; Peters, A.H.; Gunther, T.; Buettner, R.; Schule, R. LSD1 demethylates repressive histone marks to promote androgenreceptor-dependent transcription. Nature 2005, 437, 436-439.

49. Schulte, J.H.; Lim, S.; Schramm, A.; Friedrichs, N.; Koster, J.; Versteeg, R.; Ora, I.; Pajtler, K.; Klein-Hitpass, L.; Kuhfittig-Kulle, S.; et al. Lysine-specific demethylase 1 is strongly expressed in poorly differentiated neuroblastoma: Implications for therapy. Cancer Res. 2009, 69, 2065-2071. 
50. Magerl, C.; Ellinger, J.; Braunschweig, T.; Kremmer, E.; Koch, L.K.; Holler, T.; Buttner, R.; Luscher, B.; Gutgemann, I. H3K4 dimethylation in hepatocellular carcinoma is rare compared with other hepatobiliary and gastrointestinal carcinomas and correlates with expression of the methylase Ash2 and the demethylase LSD1. Hum. Pathol. 2010, 41, 181-189.

51. Wang, Y.; Zhang, H.; Chen, Y.; Sun, Y.; Yang, F.; Yu, W.; Liang, J.; Sun, L.; Yang, X.; Shi, L.; et al. LSD1 is a subunit of the NuRD complex and targets the metastasis programs in breast cancer. Cell 2009, 138, 660-672.

52. Zeng, J.; Ge, Z.; Wang, L.; Li, Q.; Wang, N.; Bjorkholm, M.; Jia, J.; Xu, D. The histone demethylase RBP2 Is overexpressed in gastric cancer and its inhibition triggers senescence of cancer cells. Gastroenterology 2010, 138, 981-992.

53. Van Zutven, L.J.; Onen, E.; Velthuizen, S.C.; van Drunen, E.; von Bergh, A.R.; van den HeuvelEibrink, M.M.; Veronese, A.; Mecucci, C.; Negrini, M.; et al. Identification of NUP98 abnormalities in acute leukemia: JARID1A (12p13) as a new partner gene. Genes Chromosomes Cancer 2006, 45, 437-446.

54. Barrett, A.; Santangelo, S.; Tan, K.; Catchpole, S.; Roberts, K.; Spencer-Dene, B.; Hall, D.; Scibetta, A.; Burchell, J.; Verdin, E.; et al. Breast cancer associated transcriptional repressor PLU-1/JARID1B interacts directly with histone deacetylases. Int. J. Cancer 2007, 121, 265-275.

55. Liggins, A.P.; Lim, S.H.; Soilleux, E.J.; Pulford, K.; Banham, A.H. A panel of cancer-testis genes exhibiting broad-spectrum expression in haematological malignancies. Cancer Immun. 2010, 10, 8.

56. Lu, P.J.; Sundquist, K.; Baeckstrom, D.; Poulsom, R.; Hanby, A.; Meier-Ewert, S.; Jones, T.; Mitchell, M.; Pitha-Rowe, P.; Freemont, P.; Taylor-Papadimitriou, J. A novel gene (PLU-1) containing highly conserved putative DNA/chromatin binding motifs is specifically up-regulated in breast cancer. Biol. Chem. 1999, 274, 15633-15645.

57. Yamane, K.; Tateishi, K.; Klose, R.J.; Fang, J.; Fabrizio, L.A.; Erdjument-Bromage, H.; Taylor-Papadimitriou, J.; Tempst, P.; Zhang, Y. PLU-1 is an H3K4 demethylase involved in transcriptional repression and breast cancer cell proliferation. Mol. Cell 2007, 25, 801-812.

58. Xiang, Y.; Zhu, Z.; Han, G.; Ye, X.; Xu, B.; Peng, Z.; Ma, Y.; Yu, Y.; Lin, H.; Chen, A.P.; et al. JARID1B is a histone H3 lysine 4 demethylase up-regulated in prostate cancer. Proc. Natl. Acad. Sci. USA 2007, 104, 19226-19231.

59. Kim, J.; Shin, S.; Subramaniam, M.; Bruinsma, E.; Kim, T.D.; Hawse, J.R.; Spelsberg, T.C.; Janknecht, R. Histone demethylase JARID1B/KDM5B is a corepressor of TIEG1/KLF10. Biochem. Biophys. Res. Commun. 2010, 401, 412-416.

60. Catchpole, S.; Spencer-Dene, B.; Hall, D.; Santangelo, S.; Rosewell, I.; Guenatri, M.; Beatson, R.; Scibetta, A.G.; Burchell, J.M.; Taylor-Papadimitriou, J. PLU-1/JARID1B/KDM5B is required for embryonic survival and contributes to cell proliferation in the mammary gland and in ER+ breast cancer cells. Int. J. Oncol. 2011, 38, 1267-1277.

61. Ma, X.D.; Han, H.D.; Huang, Y.Q.; Zou, Y. The effects of JARID1B siRNA on proliferation and apoptosis in HL-60 cell. Zhonghua Xue Ye Xue Za Zhi 2012, 33, 392-396.

62. Niu, X.; Zhang, T.; Liao, L.; Zhou, L.; Lindner, D.J.; Zhou, M.; Rini, B.; Yan, Q.; Yang, H. The von Hippel-Lindau tumor suppressor protein regulates gene expression and tumor growth through histone demethylase JARID1C. Oncogene 2012, 31, 776-786. 
63. Smith, J.A.; White, E.A.; Sowa, M.E.; Powell, M.L.; Ottinger, M.; Harper, J.W.; Howley, P.M. Genome-wide siRNA screen identifies SMCX, EP400, and Brd4 as E2-dependent regulators of human papillomavirus oncogene expression. Proc. Natl. Acad. Sci. USA 2010, 107, 3752-3757.

64. Varela, I.; Tarpey, P.; Raine, K.; Huang, D.; Ong, C.K.; Stephens, P.; Davies, H.; Jones, D.; Lin, M.L.; Teague, J.; et al. Exome sequencing identifies frequent mutation of the SWI/SNF complex gene PBRM1 in renal carcinoma. Nature 2011, 469, 539-542.

65. He, J.; Nguyen, A.T.; Zhang, Y. KDM2b/JHDM1b, an H3K36me2-specific demethylase, is required for initiation and maintenance of acute myeloid leukemia. Blood 2011, 117, 3869-3880.

66. Nakamura, S.; Tan, L.; Nagata, Y.; Takemura, T.; Asahina, A.; Yokota, D.; Yagyu, T.; Shibata, K.; Fujisawa, S.; Ohnishi, K. JmjC-domain containing histone demethylase 1B-mediated p15(Ink4b) suppression promotes the proliferation of leukemic progenitor cells through modulation of cell cycle progression in acute myeloid leukemia. Mol. Carcinog. 2011, doi:10.1002/mc.20878.

67. Suzuki, T.; Minehata, K.; Akagi, K.; Jenkins, N.A.; Copeland, N.G. Tumor suppressor gene identification using retroviral insertional mutagenesis in Blm-deficient mice. EMBO J. 2006, 25, $3422-3431$.

68. Frescas, D.; Guardavaccaro, D.; Bassermann, F.; Koyama-Nasu, R.; Pagano, M. JHDM1B/FBXL10 is a nucleolar protein that represses transcription of ribosomal RNA genes. Nature 2007, 450, 309-313.

69. Cloos, P.A.; Christensen, J.; Agger, K.; Maiolica, A.; Rappsilber, J.; Antal, T.; Hansen, K.H.; Helin, K. The putative oncogene GASC1 demethylates tri- and dimethylated lysine 9 on histone H3. Nature 2006, 442, 307-311.

70. Italiano, A.; Attias, R.; Aurias, A.; Perot, G.; Burel-Vandenbos, F.; Otto, J.; Venissac, N.; Pedeutour, F. Molecular cytogenetic characterization of a metastatic lung sarcomatoid carcinoma: 9p23 Neocentromere and 9p23-p24 amplification including JAK2 and JMJD2C. Cancer Genet. Cytogenet. 2006, 167, 122-130.

71. Helias, C.; Struski, S.; Gervais, C.; Leymarie, V.; Mauvieux, L.; Herbrecht, R.; Lessard, M. Polycythemia vera transforming to acute myeloid leukemia and complex abnormalities including $9 p$ homogeneously staining region with amplification of MLLT3, JMJD2C, JAK2, and SMARCA2. Cancer Genet. Cytogenet. 2008, 180, 51-55.

72. Nacheva, E.P.; Brazma, D.; Virgili, A.; Howard-Reeves, J.; Chanalaris, A.; Gancheva, K.; Apostolova, M.; Valganon, M.; Mazzullo, H.; Grace, C. Deletions of immunoglobulin heavy chain and $\mathrm{T}$ cell receptor gene regions are uniquely associated with lymphoid blast transformation of chronic myeloid leukemia. BMC Genomics 2010, 11, 41.

73. Min, D.J.; Licht, J.D. Partners in crime: Genes within an amplicon collude to globally deregulate chromatin in lymphoma. Cancer Cell 2010, 18, 539-541.

74. Rui, L.; Emre, N.C.; Kruhlak, M.J.; Chung, H.J.; Steidl, C.; Slack, G.; Wright, G.W.; Lenz, G.; Ngo, V.N.; Shaffer, A.L.; et al. Cooperative epigenetic modulation by cancer amplicon genes. Cancer Cell 2010, 18, 590-605.

75. Liu, G.; Bollig-Fischer, A.; Kreike, B.; van de Vijver, M.J.; Abrams, J.; Ethier, S.P.; Yang, Z.Q. Genomic amplification and oncogenic properties of the GASC1 histone demethylase gene in breast cancer. Oncogene 2009, 28, 4491-4500. 
76. Wu, J.; Liu, S.; Liu, G.; Dombkowski, A.; Abrams, J.; Martin-Trevino, R.; Wicha, M.S.; Ethier, S.P.; Yang, Z.Q. Identification and functional analysis of 9p24 amplified genes in human breast cancer. Oncogene 2012, 31, 333-341.

77. Fischer, U.; Wullich, B.; Sattler, H.P.; Gottert, E.; Zang, K.D.; Meese, E. DNA amplifications on chromosomes 7, 9 and 12 in glioblastoma detected by reverse chromosome painting. Eur. J. Cancer 1994, 30A, 1124-1127.

78. Haque, A.; Banik, N.L.; Ray, S.K. Molecular alterations in glioblastoma: Potential targets for immunotherapy. Prog. Mol. Biol. Transl. Sci. 2011, 98, 187-234.

79. Margareto, J.; Leis, O.; Larrarte, E.; Pomposo, I.C.; Garibi, J.M.; Lafuente, J.V. DNA copy number variation and gene expression analyses reveal the implication of specific oncogenes and genes in GBM. Cancer Investig. 2009, 27, 541-548.

80. Vinatzer, U.; Gollinger, M.; Mullauer, L.; Raderer, M.; Chott, A.; Streubel, B. Mucosa-associated lymphoid tissue lymphoma: Novel translocations including rearrangements of ODZ2, JMJD2C, and CNN3. Clin. Cancer Res. 2008, 14, 6426-6431.

81. Ehrbrecht, A.; Muller, U.; Wolter, M.; Hoischen, A.; Koch, A.; Radlwimmer, B.; Actor, B.; Mincheva, A.; Pietsch, T.; Lichter, P.; et al. Comprehensive genomic analysis of desmoplastic medulloblastomas: Identification of novel amplified genes and separate evaluation of the different histological components. J. Pathol. 2006, 208, 554-563.

82. Yang, Z.Q.; Imoto, I.; Fukuda, Y.; Pimkhaokham, A.; Shimada, Y.; Imamura, M.; Sugano, S.; Nakamura, Y.; Inazawa, J. Identification of a novel gene, GASC1, within an amplicon at 9p23-24 frequently detected in esophageal cancer cell lines. Cancer Res. 2000, 60, 4735-4739.

83. Chen, Z.; Wang, L.; Wang, Q.; Li, W. Histone modifications and chromatin organization in prostate cancer. Epigenomics 2010, 2, 551-560.

84. Shin, S.; Janknecht, R. Activation of androgen receptor by histone demethylases JMJD2A and JMJD2D. Biochem. Biophys. Res. Commun. 2007, 359, 742-746.

85. Chang, P.C.; Fitzgerald, L.D.; Hsia, D.A.; Izumiya, Y.; Wu, C.Y.; Hsieh, W.P.; Lin, S.F.; Campbell, M.; Lam, K.S.; Luciw, P.A.; et al. Histone demethylase JMJD2A regulates Kaposi's sarcoma-associated herpesvirus replication and is targeted by a viral transcriptional factor. J. Virol. 2011, 85, 3283-3293.

86. Li, B.X.; Zhang, M.C.; Luo, C.L.; Yang, P.; Li, H.; Xu, H.M.; Xu, H.F.; Shen, Y.W.; Xue, A.M.; Zhao, Z.Q. Effects of RNA interference-mediated gene silencing of JMJD2A on human breast cancer cell line MDA-MB-231 in vitro. J. Exp. Clin. Cancer Res. 2011, 30, 90.

87. Kim, T.D.; Shin, S.; Berry, W.L.; Oh, S.; Janknecht, R. The JMJD2A demethylase regulates apoptosis and proliferation in colon cancer cells. J. Cell. Biochem. 2011, 113, 368-1376.

88. Anderton, J.A.; Bose, S.; Vockerodt, M.; Vrzalikova, K.; Wei, W.; Kuo, M.; Helin, K.; Christensen, J.; Rowe, M.; Murray, P.G.; et al. The H3K27me3 demethylase, KDM6B, is induced by Epstein-Barr virus and over-expressed in Hodgkin's Lymphoma. Oncogene 2011, 30, 2037-2043.

89. Martinelli, P.; Bonetti, P.; Sironi, C.; Pruneri, G.; Fumagalli, C.; Raviele, P.R.; Volorio, S.; Pileri, S.; Chiarle, R.; McDuff, F.K.; et al. The lymphoma-associated NPM-ALK oncogene elicits a p16INK4a/pRb-dependent tumor-suppressive pathway. Blood 2011, 117, 6617-6626. 
90. Pereira, F.; Barbachano, A.; Silva, J.; Bonilla, F.; Campbell, M.J.; Munoz, A.; Larriba, M.J. KDM6B/JMJD3 histone demethylase is induced by vitamin D and modulates its effects in colon cancer cells. Hum. Mol. Genet. 2011, 20, 4655-4665.

91. Dalgliesh, G.L.; Furge, K.; Greenman, C.; Chen, L.; Bignell, G.; Butler, A.; Davies, H.; Edkins, S.; Hardy, C.; Latimer, C.; et al. Systematic sequencing of renal carcinoma reveals inactivation of histone modifying genes. Nature 2010, 463, 360-363.

92. Gui, Y.; Guo, G.; Huang, Y.; Hu, X.; Tang, A.; Gao, S.; Wu, R.; Chen, C.; Li, X.; Zhou, L.; et al. Frequent mutations of chromatin remodeling genes in transitional cell carcinoma of the bladder. Nat. Genet. 2011, 43, 875-878.

93. Mar, B.G.; Bullinger, L.; Basu, E.; Schlis, K.; Silverman, L.B.; Dohner, K.; Armstrong, S.A. Sequencing histone-modifying enzymes identifies UTX mutations in acute lymphoblastic leukemia. Leukemia 2012, 26, 1881-1883.

94. McDevitt, M.A. Clinical applications of epigenetic markers and epigenetic profiling in myeloid malignancies. Semin. Oncol. 2012, 39, 109-122.

95. Muramatsu, H.; Makishima, H.; Maciejewski, J.P. Chronic myelomonocytic leukemia and atypical chronic myeloid leukemia: Novel pathogenetic lesions. Semin. Oncol. 2012, 39, 67-73.

96. Van Haaften, G.; Dalgliesh, G.L.; Davies, H.; Chen, L.; Bignell, G.; Greenman, C.; Edkins, S.; Hardy, C.; O'Meara, S.; Teague, J.; et al. Somatic mutations of the histone H3K27 demethylase gene UTX in human cancer. Nat. Genet. 2009, 41, 521-523.

97. Shi, Y.J.; Matson, C.; Lan, F.; Iwase, S.; Baba, T.; Shi, Y. Regulation of LSD1 histone demethylase activity by its associated factors. Mol. Cell 2005, 19, 857-864.

98. Yang, M.; Gocke, C.B.; Luo, X.; Borek, D.; Tomchick, D.R.; Machius, M.; Otwinowski, Z.; Yu, H. Structural basis for CoREST-dependent demethylation of nucleosomes by the human LSD1 histone demethylase. Mol. Cell 2006, 23, 377-387.

99. Baron, R.; Binda, C.; Tortorici, M.; McCammon, J.A.; Mattevi, A. Molecular mimicry and ligand recognition in binding and catalysis by the histone demethylase LSD1-CoREST complex. Structure 2011, 19, 212-220.

100. Adamo, A.; Sese, B.; Boue, S.; Castano, J.; Paramonov, I.; Barrero, M.J.; Izpisua Belmonte, J.C. LSD1 regulates the balance between self-renewal and differentiation in human embryonic stem cells. Nat. Cell Biol. 2011, 13, 652-659.

101. Nicholson, T.B.; Su, H.; Hevi, S.; Wang, J.; Bajko, J.; Li, M.; Valdez, R.; Loureiro, J.; Cheng, X.; Li, E.; et al. Defective heart development in hypomorphic LSD1 mice. Cell Res. 2011, doi:10.1038/cr.2011.194.

102. Sun, G.; Ye, P.; Murai, K.; Lang, M.F.; Li, S.; Zhang, H.; Li, W.; Fu, C.; Yin, J.; Wang, A.; et al. miR-137 Forms a regulatory loop with nuclear receptor TLX and LSD1 in neural stem cells. Nat. Commun. 2011, 2, 529.

103. Choi, J.; Jang, H.; Kim, H.; Kim, S.T.; Cho, E.J.; Youn, H.D. Histone demethylase LSD1 is required to induce skeletal muscle differentiation by regulating myogenic factors. Biochem. Biophys. Res. Commun. 2010, 401, 327-332.

104. Hino, S.; Sakamoto, A.; Nagaoka, K.; Anan, K.; Wang, Y.; Mimasu, S.; Umehara, T.; Yokoyama, S.; Kosai, K.; Nakao, M. FAD-dependent lysine-specific demethylase-1 regulates cellular energy expenditure. Nat. Commun. 2012, 3, 758. 
105. Janzer, A.; Lim, S.; Fronhoffs, F.; Niazy, N.; Buettner, R.; Kirfel, J. Lysine-specific demethylase 1 (LSD1) and histone deacetylase 1 (HDAC1) synergistically repress proinflammatory cytokines and classical complement pathway components. Biochem. Biophys. Res. Commun. 2012, 421, 665-670.

106. Sprussel, A.; Schulte, J.H.; Weber, S.; Necke, M.; Handschke, K.; Thor, T.; Pajtler, K.W.; Schramm, A.; Konig, K.; Diehl, L.; et al. Lysine-specific demethylase 1 restricts hematopoietic progenitor proliferation and is essential for terminal differentiation. Leukemia 2012, doi:10.1038/leu.2012.157.

107. Stavropoulos, P.; Blobel, G.; Hoelz, A. Crystal structure and mechanism of human lysine-specific demethylase-1. Nat. Struct. Mol. Biol. 2006, 13, 626-632.

108. Mimasu, S.; Umezawa, N.; Sato, S.; Higuchi, T.; Umehara, T.; Yokoyama, S. Structurally designed trans-2-phenylcyclopropylamine derivatives potently inhibit histone demethylase LSD1/KDM1. Biochemistry 2010, 49, 6494-6503.

109. Huang, Y.; Marton, L.J.; Woster, P.M.; Casero, R.A. Polyamine analogues targeting epigenetic gene regulation. Essays Biochem. 2009, 46, 95-110.

110. Yu, V.; Fisch, T.; Long, A.M.; Tang, J.; Lee, J.H.; Hierl, M.; Chen, H.; Yakowec, P.; Schwandner, R.; Emkey, R. High-throughput TR-FRET assays for identifying inhibitors of LSD1 and JMJD2C histone lysine demethylases. J. Biomol. Screen. 2012, 17, 27-38.

111. Yang, M.; Culhane, J.C.; Szewczuk, L.M.; Gocke, C.B.; Brautigam, C.A.; Tomchick, D.R.; Machius, M.; Cole, P.A.; Yu, H. Structural basis of histone demethylation by LSD1 revealed by suicide inactivation. Nat. Struct. Mol. Biol. 2007, 14, 535-539.

112. Chen, Y.; Jie, W.; Yan, W.; Zhou, K.; Xiao, Y. Lysine-specific histone demethylase 1 (LSD1): A potential molecular target for tumor therapy. Crit. Rev. Eukaryot. Gene Expr. 2012, 22, 53-59.

113. Karytinos, A.; Forneris, F.; Profumo, A.; Ciossani, G.; Battaglioli, E.; Binda, C.; Mattevi, A. A novel mammalian flavin-dependent histone demethylase. Biol. Chem. 2009, 284, 17775-17782.

114. Fang, R.; Barbera, A.J.; Xu, Y.; Rutenberg, M.; Leonor, T.; Bi, Q.; Lan, F.; Mei, P.; Yuan, G.C.; Lian, C; et al. Human LSD2/KDM1b/AOF1 regulates gene transcription by modulating intragenic H3K4me2 methylation. Mol. Cell 2010, 39, 222-233.

115. Van Essen, D.; Zhu, Y.; Saccani, S. A feed-forward circuit controlling inducible NF-kappaB target gene activation by promoter histone demethylation. Mol. Cell 2010, 39, 750-760.

116. Ciccone, D.N.; Su, H.; Hevi, S.; Gay, F.; Lei, H.; Bajko, J.; Xu, G.; Li, E.; Chen, T. KDM1B is a histone H3K4 demethylase required to establish maternal genomic imprints. Nature 2009, 461, 415-418.

117. Lin, S.L. Concise review: Deciphering the mechanism behind induced pluripotent stem cell generation. Stem Cells 2011, 29, 1645-1649.

118. Binda, C.; Valente, S.; Romanenghi, M.; Pilotto, S.; Cirilli, R.; Karytinos, A.; Ciossani, G.; Botrugno, O.A.; Forneris, F.; Tardugno, M.; et al. Biochemical, structural, and biological evaluation of tranylcypromine derivatives as inhibitors of histone demethylases LSD1 and LSD2. J. Am. Chem. Soc. 2010, 132, 6827-6833.

119. Alvarez-Saavedra, M.; Antoun, G.; Yanagiya, A.; Oliva-Hernandez, R.; Cornejo-Palma, D.; Perez-Iratxeta, C.; Sonenberg, N.; Cheng, H.Y. miRNA-132 Orchestrates chromatin remodeling and translational control of the circadian clock. Hum. Mol. Genet. 2011, 20, 731-751. 
120. DiTacchio, L.; Le, H.D.; Vollmers, C.; Hatori, M.; Witcher, M.; Secombe, J.; Panda, S. Histone lysine demethylase JARID1a activates CLOCK-BMAL1 and influences the circadian clock. Science 2011, 333, 1881-1885.

121. Christensen, J.; Agger, K.; Cloos, P.A.; Pasini, D.; Rose, S.; Sennels, L.; Rappsilber, J.; Hansen, K.H.; Salcini, A.E.; Helin, K. RBP2 belongs to a family of demethylases, specific for tri-and dimethylated lysine 4 on histone 3. Cell 2007, 128, 1063-1076.

122. Lee, C.H.; Alpert, B.O.; Sankaranarayanan, P.; Alter, O. GSVD comparison of patient-matched normal and tumor aCGH profiles reveals global copy-number alterations predicting glioblastoma multiforme survival. PLoS One 2012, 7, e30098.

123. Sharma, S.V.; Lee, D.Y.; Li, B.; Quinlan, M.P.; Takahashi, F.; Maheswaran, S.; McDermott, U.; Azizian, N.; Zou, L.; Fischbach, M.A.; et al. A chromatin-mediated reversible drug-tolerant state in cancer cell subpopulations. Cell 2010, 141, 69-80.

124. Frank, S.A.; Rosner, M.R. Nonheritable cellular variability accelerates the evolutionary processes of cancer. PLoS Biol. 2012, 10, e1001296.

125. Pointon, J.J.; Harvey, D.; Karaderi, T.; Appleton, L.H.; Farrar, C.; Wordsworth, B.P. The histone demethylase JARID1A is associated with susceptibility to ankylosing spondylitis. Genes Immun. 2011, 12, 395-398.

126. Zhao, M.; Liang, G.; Wu, X.; Wang, S.; Zhang, P.; Su, Y.; Yin, H.; Tan, Y.; Zhang, J.; Lu, Q. Abnormal epigenetic modifications in peripheral blood mononuclear cells from patients with alopecia areata. Br. J. Dermatol. 2012, 166, 226-273.

127. Liefke, R.; Oswald, F.; Alvarado, C.; Ferres-Marco, D.; Mittler, G.; Rodriguez, P.; Dominguez, M.; Borggrefe, T. Histone demethylase KDM5A is an integral part of the core Notch-RBP-J repressor complex. Genes Dev. 2010, 24, 590-601.

128. Chicas, A.; Kapoor, A.; Wang, X.; Aksoy, O.; Evertts, A.G.; Zhang, M.Q.; Garcia, B.A.; Bernstein, E.; Lowe, S.W. H3K4 demethylation by Jarid1a and Jarid1b contributes to retinoblastoma-mediated gene silencing during cellular senescence. Proc. Natl. Acad. Sci. USA 2012, 109, 8971-8976.

129. Dey, B.K.; Stalker, L.; Schnerch, A.; Bhatia, M.; Taylor-Papidimitriou, J.; Wynder, C. The histone demethylase KDM5b/JARID1b plays a role in cell fate decisions by blocking terminal differentiation. Mol. Cell. Biol. 2008, 28, 5312-5327.

130. Schmitz, S.U.; Albert, M.; Malatesta, M.; Morey, L.; Johansen, J.V.; Bak, M.; Tommerup, N.; Abarrategui, I.; Helin, K. Jaridlb targets genes regulating development and is involved in neural differentiation. EMBO J. 2011, 30, 4586-4600.

131. Scibetta, A.G.; Santangelo, S.; Coleman, J.; Hall, D.; Chaplin, T.; Copier, J.; Catchpole, S.; Burchell, J.; Taylor-Papadimitriou, J. Functional analysis of the transcription repressor PLU-1/JARID1B. Mol. Cell. Biol. 2007, 27, 7220-7235.

132. Tarantino, C.; Paolella, G.; Cozzuto, L.; Minopoli, G.; Pastore, L.; Parisi, S.; Russo, T. miRNA 34a, 100, and 137 Modulate differentiation of mouse embryonic stem cells. FASEB J. 2010, 24, $3255-3263$. 
133. Kristensen, L.H.; Nielsen, A.L.; Helgstrand, C.; Lees, M.; Cloos, P.; Kastrup, J.S.; Helin, K.; Olsen, L.; Gajhede, M. Studies of H3K4me3 demethylation by KDM5B/Jarid1B/PLU1 reveals strong substrate recognition in vitro and identifies 2,4-pyridine-dicarboxylic acid as an in vitro and in cell inhibitor. FEBS J. 2012, 279, 1905-1914.

134. Akbarian, S.; Huang, H.S. Epigenetic regulation in human brain-focus on histone lysine methylation. Biol. Psychiatry 2009, 65, 198-203.

135. Xu, J.; Andreassi, M. Reversible histone methylation regulates brain gene expression and behavior. Horm. Behav. 2011, 59, 383-392.

136. Abidi, F.E.; Holloway, L.; Moore, C.A.; Weaver, D.D.; Simensen, R.J.; Stevenson, R.E.; Rogers, R.C.; Schwartz, C.E. Mutations in JARID1C are associated with X-linked mental retardation, short stature and hyperreflexia. J. Med. Genet. 2008, 45, 787-793.

137. Jensen, L.R.; Bartenschlager, H.; Rujirabanjerd, S.; Tzschach, A.; Numann, A.; Janecke, A.R.; Sporle, R.; Stricker, S.; Raynaud, M.; Nelson, J.; et al. A distinctive gene expression fingerprint in mentally retarded male patients reflects disease-causing defects in the histone demethylase KDM5C. Pathogenetics 2010, 3, 2.

138. Santos-Reboucas, C.B.; Fintelman-Rodrigues, N.; Jensen, L.R.; Kuss, A.W.; Ribeiro, M.G.; Campos, M., Jr.; Santos, J.M.; Pimentel, M.M. A novel nonsense mutation in KDM5C/JARID1C gene causing intellectual disability, short stature and speech delay. Neurosci. Lett. 2011, 498, 67-71.

139. Adegbola, A.; Gao, H.; Sommer, S.; Browning, M. A novel mutation in JARID1C/SMCX in a patient with autism spectrum disorder (ASD). Am. J. Med. Genet. A 2008, 146A, 505-511.

140. Upadhyay, A.K.; Rotili, D.; Han, J.W.; Hu, R.; Chang, Y.; Labella, D.; Zhang, X.; Yoon, Y.S.; Mai, A.; Cheng, X. An analog of BIX-01294 selectively inhibits a family of histone H3 lysine 9 Jumonji demethylases. J. Mol. Biol. 2012, 416, 319-327.

141. He, J.; Kallin, E.M.; Tsukada, Y.; Zhang, Y. The H3K36 demethylase Jhdm1b/Kdm2b regulates cell proliferation and senescence through p15(Ink4b). Nat. Struct. Mol. Biol. 2008, 15, 1169-1175.

142. Tzatsos, A.; Paskaleva, P.; Lymperi, S.; Contino, G.; Stoykova, S.; Chen, Z.; Wong, K.K.; Bardeesy, N. Lysine-specific demethylase 2B (KDM2B)-let-7-enhancer of zester homolog 2 (EZH2) pathway regulates cell cycle progression and senescence in primary cells. Biol. Chem. 2011, 286, 33061-33069.

143. Wang, T.; Chen, K.; Zeng, X.; Yang, J.; Wu, Y.; Shi, X.; Qin, B.; Zeng, L.; Esteban, M.A.; Pan, G.; et al. The histone demethylases Jhdm1a/1b enhance somatic cell reprogramming in a vitamin-C-dependent manner. Cell Stem Cell 2011, 9, 575-587.

144. Bredel, M.; Bredel, C.; Juric, D.; Harsh, G.R.; Vogel, H.; Recht, L.D.; Sikic, B.I. Functional network analysis reveals extended gliomagenesis pathway maps and three novel MYC-interacting genes in human gliomas. Cancer Res. 2005, 65, 8679-8689.

145. Freije, W.A.; Castro-Vargas, F.E.; Fang, Z.; Horvath, S.; Cloughesy, T.; Liau, L.M.; Mischel, P.S.; Nelson, S.F. Gene expression profiling of gliomas strongly predicts survival. Cancer Res. 2004, 64, 6503-6510.

146. Lizcano, F.; Romero, C.; Vargas, D. Regulation of adipogenesis by nuclear receptor PPARgamma is modulated by the histone demethylase JMJD2C. Genet. Mol. Biol. 2011, 34, 19-24. 
147. Pollard, P.J.; Loenarz, C.; Mole, D.R.; McDonough, M.A.; Gleadle, J.M.; Schofield, C.J.; Ratcliffe, P.J. Regulation of Jumonji-domain-containing histone demethylases by hypoxia-inducible factor (HIF)-1alpha. Biochem. J. 2008, 416, 387-394.

148. Loh, Y.H.; Zhang, W.; Chen, X.; George, J.; Ng, H.H. Jmjd1a and Jmjd2c histone H3 Lys 9 demethylases regulate self-renewal in embryonic stem cells. Genes Dev. 2007, 21, 2545-2557.

149. Katoh, Y.; Katoh, M. Comparative integromics on JMJD2A, JMJD2B and JMJD2C: Preferential expression of JMJD2C in undifferentiated ES cells. Int. J. Mol. Med. 2007, 20, 269-273.

150. Kantojarvi, K.; Onkamo, P.; Vanhala, R.; Alen, R.; Hedman, M.; Sajantila, A.; Nieminen-von Wendt, T.; Jarvela, I. Analysis of 9p24 and 11p12-13 regions in autism spectrum disorders: rs1340513 In the JMJD2C gene is associated with ASDs in Finnish sample. Psychiatr. Genet. 2010, 20, 102-108.

151. Ponnaluri, V.K.; Vavilala, D.T.; Mukherji, M. Studies on substrate specificity of Jmjd2a-c histone demethylases. Biochem. Biophys. Res. Commun. 2011, 405, 588-592.

152. Gray, S.G.; Iglesias, A.H.; Lizcano, F.; Villanueva, R.; Camelo, S.; Jingu, H.; Teh, B.T.; Koibuchi, N.; Chin, W.W.; Kokkotou, E.; et al. Functional characterization of JMJD2A, a histone deacetylase- and retinoblastoma-binding protein. Biol. Chem. 2005, 280, 28507-28518.

153. Klose, R.J.; Yamane, K.; Bae, Y.; Zhang, D.; Erdjument-Bromage, H.; Tempst, P.; Wong, J.; Zhang, Y. The transcriptional repressor JHDM3A demethylates trimethyl histone H3 lysine 9 and lysine 36. Nature 2006, 442, 312-316.

154. Verrier, L.; Escaffit, F.; Chailleux, C.; Trouche, D.; Vandromme, M. A new isoform of the histone demethylase JMJD2A/KDM4A is required for skeletal muscle differentiation. PLoS Genet. 2011, 7, e1001390.

155. Mallette, F.A.; Mattiroli, F.; Cui, G.; Young, L.C.; Hendzel, M.J.; Mer, G.; Sixma, T.K.; Richard, S. RNF8- and RNF168-dependent degradation of KDM4A/JMJD2A triggers 53BP1 recruitment to DNA damage sites. EMBO J. 2012, 31, 1865-1878.

156. Zhang, Q.J.; Chen, H.Z.; Wang, L.; Liu, D.P.; Hill, J.A.; Liu, Z.P. The histone trimethyllysine demethylase JMJD2A promotes cardiac hypertrophy in response to hypertrophic stimuli in mice. J. Clin. Invest. 2011, 121, 2447-2456.

157. Couture, J.F.; Collazo, E.; Ortiz-Tello, P.A.; Brunzelle, J.S.; Trievel, R.C. Specificity and mechanism of JMJD2A, a trimethyllysine-specific histone demethylase. Nat. Struct. Mol. Biol. 2007, 14, 689-695.

158. Huang, Y.; Fang, J.; Bedford, M.T.; Zhang, Y.; Xu, R.M. Recognition of histone H3 lysine-4 methylation by the double tudor domain of JMJD2A. Science 2006, 312, 748-751.

159. Ng, S.S.; Kavanagh, K.L.; McDonough, M.A.; Butler, D.; Pilka, E.S.; Lienard, B.M.; Bray, J.E.; Savitsky, P.; Gileadi, O.; von Delft, F.; et al. Crystal structures of histone demethylase JMJD2A reveal basis for substrate specificity. Nature 2007, 448, 87-91.

160. zboyaci, M.; Gursoy, A.; Erman, B.; Keskin, O. Molecular recognition of H3/H4 histone tails by the tudor domains of JMJD2A: A comparative molecular dynamics simulations study. PLoS One 2011, 6, e14765.

161. Sanli, D.; Keskin, O.; Gursoy, A.; Erman, B. Structural cooperativity in histone H3 tail modifications. Protein Sci. 2011, 20, 1982-1990. 
162. Rose, N.R.; Woon, E.C.; Kingham, G.L.; King, O.N.; Mecinovic, J.; Clifton, I.J.; Ng, S.S.; Talib-Hardy, J.; Oppermann, U.; McDonough, M.A.; et al. Selective inhibitors of the JMJD2 histone demethylases: Combined nondenaturing mass spectrometric screening and crystallographic approaches. J. Med. Chem. 2010, 53, 1810-1818.

163. Hutchinson, S.E.; Leveridge, M.V.; Heathcote, M.L.; Francis, P.; Williams, L.; Gee, M.; Munoz-Muriedas, J.; Leavens, B.; Shillings, A.; Jones, E.; et al. Enabling lead discovery for histone lysine demethylases by high-throughput RapidFire mass spectrometry. J. Biomol. Screen. 2012, 17, 39-48.

164. Xiang, Y.; Zhu, Z.; Han, G.; Lin, H.; Xu, L.; Chen, C.D. JMJD3 is a histone H3K27 demethylase. Cell Res. 2007, 17, 850-857.

165. Hong, S.; Cho, Y.W.; Yu, L.R.; Yu, H.; Veenstra, T.D.; Ge, K. Identification of JmjC domain-containing UTX and JMJD3 as histone H3 lysine 27 demethylases. Proc. Natl. Acad. Sci. USA 2007, 104, 18439-18444.

166. Issaeva, I.; Zonis, Y.; Rozovskaia, T.; Orlovsky, K.; Croce, C.M.; Nakamura, T.; Mazo, A.; Eisenbach, L.; Canaani, E. Knockdown of ALR (MLL2) reveals ALR target genes and leads to alterations in cell adhesion and growth. Mol. Cell. Biol. 2007, 27, 1889-1903.

167. Lee, M.G.; Villa, R.; Trojer, P.; Norman, J.; Yan, K.P.; Reinberg, D.; di Croce, L.; Shiekhattar, R. Demethylation of H3K27 regulates polycomb recruitment and H2A ubiquitination. Science 2007, $318,447-450$.

168. Vernimmen, D.; Lynch, M.D.; de Gobbi, M.; Garrick, D.; Sharpe, J.A.; Sloane-Stanley, J.A.; Smith, A.J.; Higgs, D.R. Polycomb eviction as a new distant enhancer function. Genes Dev. 2011, 25, 1583-1588.

169. Dahle, O.; Kumar, A.; Kuehn, M.R. Nodal signaling recruits the histone demethylase Jmjd3 to counteract polycomb-mediated repression at target genes. Sci. Signal. 2010, 3, ra48.

170. Kim, S.W.; Yoon, S.J.; Chuong, E.; Oyolu, C.; Wills, A.E.; Gupta, R.; Baker, J. Chromatin and transcriptional signatures for Nodal signaling during endoderm formation in hESCs. Dev. Biol. 2011, 357, 492-504.

171. Ohtani, K.; Vlachojannis, G.J.; Koyanagi, M.; Boeckel, J.N.; Urbich, C.; Farcas, R.; Bonig, H.; Marquez, V.E.; Zeiher, A.M.; Dimmeler, S. Epigenetic regulation of endothelial lineage committed genes in pro-angiogenic hematopoietic and endothelial progenitor cells. Circ. Res. 2011, 109, 1219-1229.

172. Sola, S.; Xavier, J.M.; Santos, D.M.; Aranha, M.M.; Morgado, A.L.; Jepsen, K.; Rodrigues, C.M. p53 interaction with JMJD3 results in its nuclear distribution during mouse neural stem cell differentiation. PLoS One 2011, 6, e18421.

173. Yasui, T.; Hirose, J.; Tsutsumi, S.; Nakamura, K.; Aburatani, H.; Tanaka, S. Epigenetic regulation of osteoclast differentiation: Possible involvement of Jmjd3 in the histone demethylation of Nfatc1. J. Bone Miner. Res. 2011, 26, 2665-2671.

174. Satoh, T.; Takeuchi, O.; Vandenbon, A.; Yasuda, K.; Tanaka, Y.; Kumagai, Y.; Miyake, T.; Matsushita, K.; Okazaki, T.; Saitoh, T.; et al. The Jmjd3-Irf4 axis regulates M2 macrophage polarization and host responses against helminth infection. Nat. Immunol. 2010, 11, 936-944. 
175. Zhang, Q.; Long, H.; Liao, J.; Zhao, M.; Liang, G.; Wu, X.; Zhang, P.; Ding, S.; Luo, S.; Lu, Q. Inhibited expression of hematopoietic progenitor kinase 1 associated with loss of jumonji domain containing 3 promoter binding contributes to autoimmunity in systemic lupus erythematosus. J. Autoimmun. 2011, 37, 180-189.

176. Ciavatta, D.J.; Yang, J.; Preston, G.A.; Badhwar, A.K.; Xiao, H.; Hewins, P.; Nester, C.M.; Pendergraft, W.F., 3rd; Magnuson, T.R.; Jennette, J.C.; et al. Epigenetic basis for aberrant upregulation of autoantigen genes in humans with ANCA vasculitis. J. Clin. Invest. 2010, 120, 3209-3219.

177. Lin, T.Y.; Cheng, Y.C.; Yang, H.C.; Lin, W.C.; Wang, C.C.; Lai, P.L.; Shieh, S.Y. Loss of the candidate tumor suppressor BTG3 triggers acute cellular senescence via the ERK-JMJD3-p16 ${ }^{\text {INK4a }}$ signaling axis. Oncogene 2011, 31, 3287-3297.

178. Svotelis, A.; Bianco, S.; Madore, J.; Huppe, G.; Nordell-Markovits, A.; Mes-Masson, A.M.; Gevry, N. H3K27 demethylation by JMJD3 at a poised enhancer of anti-apoptotic gene BCL2 determines ERalpha ligand dependency. EMBO J. 2011, 30, 3947-3961.

179. Mulji, A.; Haslam, C.; Brown, F.; Randle, R.; Karamshi, B.; Smith, J.; Eagle, R.; Munoz-Muriedas, J.; Taylor, J.; Sheikh, A.; Bridges, A.; et al. Configuration of a high-content imaging platform for hit identification and pharmacological assessment of JMJD3 demethylase enzyme inhibitors. J. Biomol. Screen. 2012, 17, 108-120.

180. Sengoku, T.; Yokoyama, S. Structural basis for histone H3 Lys 27 demethylation by UTX/KDM6A. Genes Dev. 2011, 25, 2266-2277.

181. Lee, S.; Lee, J.W.; Lee, S.K. UTX, a histone H3-lysine 27 demethylase, acts as a critical switch to activate the cardiac developmental program. Dev. Cell 2012, 22, 25-37.

182. Yap, D.B.; Walker, D.C.; Prentice, L.M.; McKinney, S.; Turashvili, G.; Mooslehner-Allen, K.; de Algara, T.R.; Fee, J.; de Tassigny, X.; Colledge, W.H.; et al. Mll5 is required for normal spermatogenesis. PLoS One 2011, 6, e27127.

183. Liu, J.; Mercher, T.; Scholl, C.; Brumme, K.; Gilliland, D.G.; Zhu, N. A functional role for the histone demethylase UTX in normal and malignant hematopoietic cells. Exp. Hematol. 2012, 40, 487-498.

184. Seenundun, S.; Rampalli, S.; Liu, Q.C.; Aziz, A.; Palii, C.; Hong, S.; Blais, A.; Brand, M.; Ge, K.; Dilworth, F.J. UTX mediates demethylation of H3K27me3 at muscle-specific genes during myogenesis. EMBO J. 2010, 29, 1401-1411.

185. Wang, J.K.; Tsai, M.C.; Poulin, G.; Adler, A.S.; Chen, S.; Liu, H.; Shi, Y.; Chang, H.Y. The histone demethylase UTX enables RB-dependent cell fate control. Genes Dev. 2010, 24, 327-332.

186. Terashima, M.; Ishimura, A.; Yoshida, M.; Suzuki, Y.; Sugano, S.; Suzuki, T. The tumor suppressor $\mathrm{Rb}$ and its related $\mathrm{Rb} 12$ genes are regulated by Utx histone demethylase. Biochem. Biophys. Res. Commun. 2010, 399, 238-244.

187. Tsai, M.C.; Wang, J.K.; Chang, H.Y. Tumor suppression by the histone demethylase UTX. Cell Cycle 2010, 9, 2043-2044.

188. Verbrugge, I.; Johnstone, R.W.; Bots, M. Promises and challenges of anticancer drugs that target the epigenome. Epigenomics 2011, 3, 547-565. 
189. Wu, Y.; Steinbergs, N.; Murray-Stewart, T.; Marton, L.J.; Casero, R.A. Oligoamine analogues in combination with 2-difluoromethylornithine synergistically induce re-expression of aberrantly silenced tumour-suppressor genes. Biochem. J. 2012, 442, 693-701.

190. Gooden, D.M.; Schmidt, D.M.; Pollock, J.A.; Kabadi, A.M.; McCafferty, D.G. Facile synthesis of substituted trans-2-arylcyclopropylamine inhibitors of the human histone demethylase LSD1 and monoamine oxidases A and B. Bioorg. Med. Chem. Lett. 2008, 18, 3047-3051.

191. Ueda, R.; Suzuki, T.; Mino, K.; Tsumoto, H.; Nakagawa, H.; Hasegawa, M.; Sasaki, R.; Mizukami, T.; Miyata, N. Identification of cell-active lysine specific demethylase 1-selective inhibitors. J. Am. Chem. Soc.2009, 131, 17536-17537.

192. Willmann, D.; Lim, S.; Wetzel, S.; Metzger, E.; Jandausch, A.; Wilk, W.; Jung, M.; Forne, I.; Imhof, A.; Janzer, A.; et al. Impairment of prostate cancer cell growth by a selective and reversible LSD1 inhibitor. Int. J. Cancer 2012, doi:10.1002/ijc. 27555.

193. Ortega-Muñoz, A.; Castro-Palomino Laria, J.; Fyfe, M.C.T. Lysine Specific Demethylase-1 Inhibitors and Their Use. WO2011035941A1, 31 March 2011.

194. Lokken, A.A.; Zeleznik-Le, N.J. Breaking the LSD1/KDM1A addiction: Therapeutic targeting of the epigenetic modifier in AML. Cancer Cell 2012, 21, 451-453.

195. Schenk, T.; Chen, W.C.; Gollner, S.; Howell, L.; Jin, L.; Hebestreit, K.; Klein, H.U.; Popescu, A.C.; Burnett, A.; Mills, K.; et al. Inhibition of the LSD1 (KDM1A) demethylase reactivates the all-trans-retinoic acid differentiation pathway in acute myeloid leukemia. Nat. Med. 2012, 18, 605-611.

196. McDonough, M.A.; McNeill, L.A.; Tilliet, M.; Papamicael, C.A.; Chen, Q.Y.; Banerji, B.; Hewitson, K.S.; Schofield, C.J. Selective inhibition of factor inhibiting hypoxia-inducible factor. J. Am. Chem. Soc.2005, 127, 7680-7681.

197. Sakurai, M.; Rose, N.R.; Schultz, L.; Quinn, A.M.; Jadhav, A.; Ng, S.S.; Oppermann, U.; Schofield, C.J.; Simeonov, A. A miniaturized screen for inhibitors of Jumonji histone demethylases. Mol. Biosyst. 2010, 6, 357-364.

198. Chang, K.H.; King, O.N.; Tumber, A.; Woon, E.C.; Heightman, T.D.; McDonough, M.A.; Schofield, C.J.; Rose, N.R. Inhibition of histone demethylases by 4-carboxy-2,2'-bipyridyl compounds. ChemMedChem 2011, 6, 759-764.

199. King, O.N.; Li, X.S.; Sakurai, M.; Kawamura, A.; Rose, N.R.; Ng, S.S.; Quinn, A.M.; Rai, G.; Mott, B.T.; Beswick, P.; et al. Quantitative high-throughput screening identifies 8-hydroxyquinolines as cell-active histone demethylase inhibitors. PLoS One 2010, 5, e15535.

200. Ulucan, O.; Keskin, O.; Erman, B.; Gursoy, A. A comparative molecular dynamics study of methylation state specificity of JMJD2A. PLoS One 2011, 6, e24664.

201. Kong, X.; Ouyang, S.; Liang, Z.; Lu, J.; Chen, L.; Shen, B.; Li, D.; Zheng, M.; Li, K.K.; Luo, C.; et al. Catalytic mechanism investigation of lysine-specific demethylase 1 (LSD1): A computational study. PLoS One 2011, 6, e25444.

202. Szewczuk, L.M.; Culhane, J.C.; Yang, M.; Majumdar, A.; Yu, H.; Cole, P.A. Mechanistic analysis of a suicide inactivator of histone demethylase LSD1. Biochemistry 2007, 46, 6892-6902. 
203. Culhane, J.C.; Wang, D.; Yen, P.M.; Cole, P.A. Comparative analysis of small molecules and histone substrate analogues as LSD1 lysine demethylase inhibitors. J. Am. Chem. Soc.2010, 132, 3164-3176.

(C) 2012 by the authors; licensee MDPI, Basel, Switzerland. This article is an open access article distributed under the terms and conditions of the Creative Commons Attribution license (http://creativecommons.org/licenses/by/3.0/). 